\title{
How to Hang in Chains: How, Where and When Eighteenth-Century Sheriffs Organised a Gibbeting
}

\begin{abstract}
The criminal corpse undertook a journey from the scaffold to the gibbet. The gibbet was commonly located near the scene of crime and in a conspicuous location, usually within sight of a major road. Customary gibbet places existed in London and in some coastal location, but usually the body was transported from the place of execution to the place of hanging in chains. Sometimes, especially earlier in our period, criminals were executed and hung in chains from the same scaffold at the scene of crime. Gibbet cages were made quickly and did not develop local styles. The scene of a gibbeting was often a rowdy and carnivalesque occasion.
\end{abstract}

Keywords Gibbet · Landscape · Technology · Location - Carnival

\section{The Process}

\section{From the Scaffold to the Gibbet}

The progress of the body from the scaffold where execution had occurred to suspension in a gibbet cage typically involved several stages. After execution, the body was left hanging for up to about an hour, both to ensure that there was no sign of life remaining (although recent research by Elizabeth Hurren suggests that in a substantial minority of

S. Tarlow, The Golden and Ghoulish Age of the Gibbet in Britain, Palgrave Historical Studies in the Criminal Corpse and its Afterlife, DOI 10.1057/978-1-137-60089-9_2 
cases even after such a long period of hanging medical death had not taken place by the time the body was removed from the scaffold) and to allow the crowds who came to view the execution enough time to inspect the body, after which it was taken down and removed to some place where it could be prepared for suspension and enclosed in irons. ${ }^{1}$ In some cases, there was a further opportunity to display the new corpse before the gibbeting, with financial benefits for those of an entrepreneurial bent. After the execution of Robert Carleton at Diss, Norfolk, in 1742, for example, his body was carried back to the house where the murder was committed and "hung up upon a balk in the middle of the room, and shewn at two pence a piece. The following day his body was put into its gibbet and displayed at Diss common". 2 Carleton's case was especially salacious, as he was found guilty of the murder of his male lover's wife.

There is little evidence about how the body was dressed for gibbeting. According to newspaper reports, the body of James Cook (d. 1832) was dressed again in the clothes in which he had been executed-probably his best clothes. The sheriffs' cravings for Shropshire 1759 itemise the costs of "plank cords and hair cloth to inclose the bodies" of two men between execution and gibbeting.

Several newspaper accounts of the preparation of the body mention that the corpse was 'tarred' or 'dipped in tar' before being gibbeted. No soft tissue of a gibbeted body survives to allow us to test this, although tarring is frequently mentioned in secondary sources, usually without additional evidence. Neither tar nor anything like it is ever itemised in the sheriffs' cravings relating to gibbetings, despite the separate listing of other apparently trivial expenses such as the cost of ale for guards, rope for a noose, or a stool for a burning. 'Dipping the body in tar' is mentioned in a few of the later newspaper accounts, such as the account of the execution and display of James Cook in 1832. It is possible that tar was used only very occasionally, despite a popular belief that tarring was a normal part of the process. Moreover, it is not clear what this 'tar' might be: if used, it is unlikely to have been a very

\footnotetext{
${ }^{1}$ Elizabeth Hurren (2015) Dissecting the Criminal Corpse: Post-Execution Punishment from the Murder Act (1752) to the Anatomy Act (1832) (Basingstoke: Palgrave).

${ }^{2}$ D. Stoker 1990. 'The tailor of Diss: sodomy and murder in a Norfolk town'. Paper published online at http://users.aber.ac.uk/das/texts/tailor_of_diss.htm, accessed $8 / 7 / 15$.
} 
heavy caulking bitumen which would obscure the individual identity of the body beyond recognition, and one can only imagine that it would make dressing the corpse and enclosing it in its gibbet cage a very difficult and sticky business. James Cook's body was dressed again in his normal clothes following tarring, so the process probably left the body more or less the same size and thus is unlikely to involve a thick, viscous or gluey kind of tar. It was certainly flammable, however, if the tale of the Chevin highwaymen is true. Cox recounts a story of no clear date which is at present unsubstantiated in the historical records: three highwaymen were apprehended and condemned to hanging in chains around the middle of the eighteenth century. Their bodies were gibbeted at the top of the Chevin near Belper in Derbyshire. "After the bodies had been hanging there a few weeks, one of the friends of the criminals set fire, at night-time, to the big gibbet that bore all three. The father of our aged informant, and two or three others of the cottagers nearby, seeing a glare of light, went up the hill, and there they saw the sickening spectacle of the three bodies blazing away in the darkness! So thoroughly did the tar aid this cremation, that the next morning only the links of the iron chains remained on the site of the gibbet". A similar story is told of the 'flaming gibbet of Galley Hill' in Bedfordshire, which may relate to the 1744 gibbeting of John Knott, who was hung in chains on 'Luton Down'. ${ }^{3}$ Whatever tarring took place, it at best only delayed the normal process of decomposition. An article in the Buckinghamshire Record Office written by J. Wharton in 1860 records that farmers living up the valley from the place where Corbett was gibbeted on Bierton Common were unable to open their windows for about a year because of the smell from the body. ${ }^{4}$

Despite folkloric - and untrue-accounts of live gibbetings, in the eighteenth and nineteenth centuries criminals were always executed before being hung in chains. In the rare cases that a condemned person managed to evade the gallows by taking their own life, hanging in chains

\footnotetext{
${ }^{3}$ J.C. Cox (1890), untitled note The Antiquary (November 1890), p. 214. The Galley Hill story is told at http://myths.e2bn.org/mythsandlegends/playstory39-the-flaminggibbet-of-galley-hill.html, but there are numerous historical errors and no original sources cited in this retelling.

${ }^{4} \mathrm{~J}$. Wharton (1863) 'The last gibbet in Buckinghamshire' Records of Buckinghamshire (vol. 2).
} 
might be carried out to confirm the death. Joseph Armstrong, sentenced to hang for the murder of his employer's wife in 1777, managed to break his own neck in prison but nevertheless was gibbeted near the home of his victim in Cheltenham "to obviate every doubt that may be raised of his not being dead". 5 This contrasts with the burial at Tewkesbury crossroads of condemned murderer William Birch, following his suicide in prison in 1791. Staked burial of suicides in the road was common for those who could be considered to have evaded punishment by taking their own lives, but gibbeting would accomplish the same goals of keeping the suicide out of consecrated ground and materially confirming their deviant status through non-normative mortuary treatment.

\section{Locating a Gibbet: The Macro-Geography of Gibbeting}

In most of England, post-mortem punishment was ordered by the circuit judge presiding at the assize court. Nevertheless, there are clear regional differences in the frequency with which gibbeting was ordered. Table 2.1 shows the frequency of gibbetings by county and decade through England and Wales. The data for the period before the Murder Act is less secure than for the later part of the eighteenth century, and numbers for the decades at the beginning of the century are very incomplete.

London (mostly recorded under "Middlesex" in the county table above) had far and away the most gibbetings. This is due in part to the fact that many of the most serious crimes were tried in London, even if committed elsewhere. London also had a huge population and wellknown social and economic problems. ${ }^{6}$ However, even in the rural provinces, there were marked differences in the frequency of hanging in chains. In the counties of Sussex, Essex, Gloucestershire and Hampshire, for example, five or six gibbetings sometimes occurred within a decade, whereas in Cornwall there were none at all during the whole period and in County Durham there was only one. These figures take no account of the size or population of a county or of the conviction rates for murder and capital crime.

\footnotetext{
${ }^{5}$ N. Darby (2011). Olde Cotswold Punishments (Stroud: The History Press), pp. 24-25.

${ }^{6} \mathrm{~J}$. White (2012) London in the eighteenth century: a great and monstrous thing (London: Bodley Head).
} 


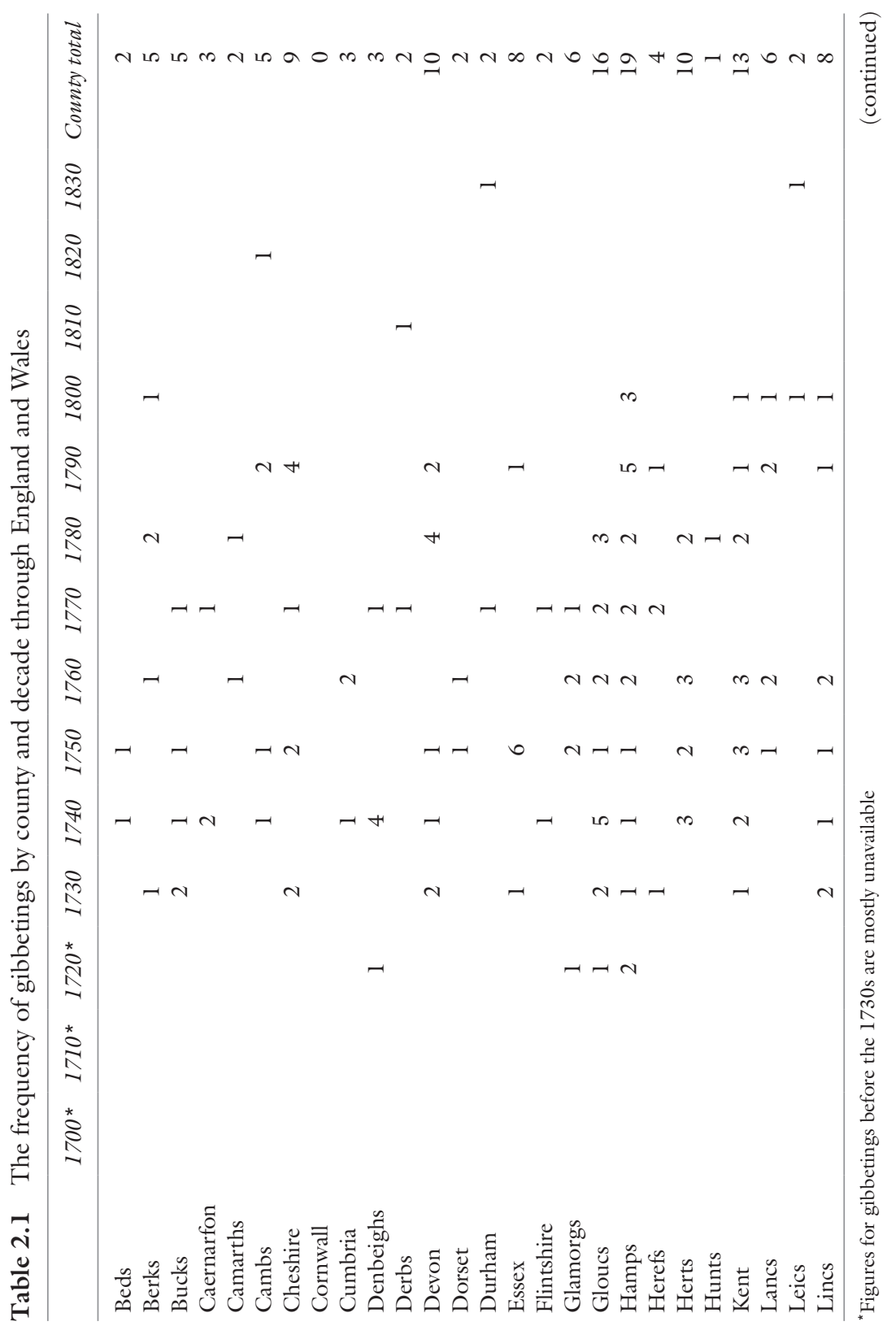


S. TARLOW

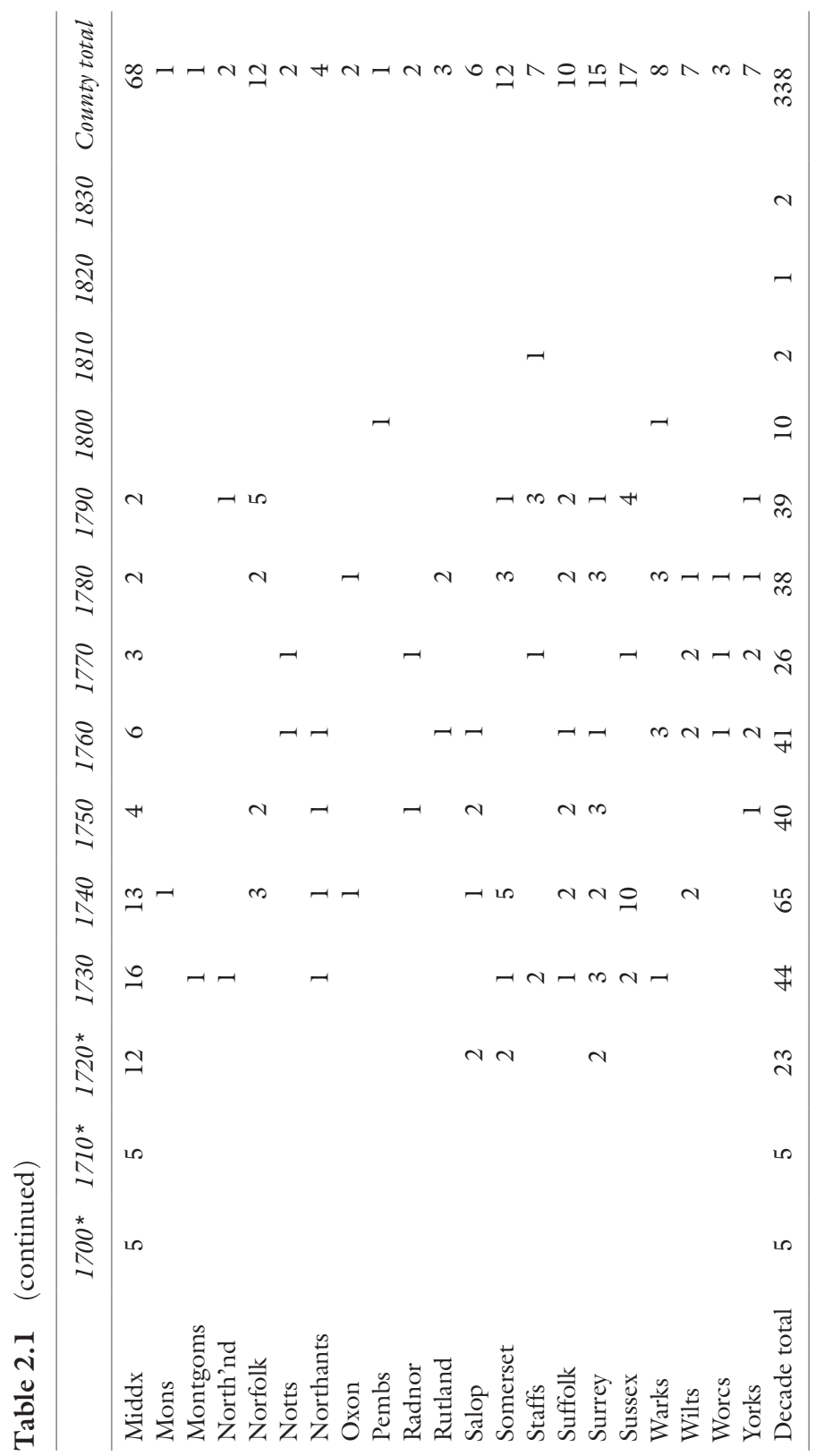




\section{The Micro-Geography of Gibbeting}

Location of gibbets was specified neither in law nor, usually, in the judge's sentence. Sometimes, the sentence of hanging in chains specified only that the gibbet should be "at a convenient location" and close to the scene of crime. My attempts to locate the original positions of gibbets have mostly been unable to pinpoint exact locations, but I have often been able to identify the place within 50 metres or so because a particular road junction or landmark is mentioned (see map). Newspaper reports are sometimes very specific: William Whittle (executed 1766 in Lancaster) was gibbeted, according to the newspaper, "at the Four Lane Ends, within forty yards of his father-in-law's house, and a hundred yards of his late dwelling house, about three miles from Preston, on the Liverpool road by way of Croston"?

There is some geographical variability in the kind of locations that were selected as suitable sites for the erection of a gibbet. London gibbets were erected in customary places on areas of open land; those convicted of maritime crimes might be hung in chains around the coast where they would be visible to shipping. Both of these types of gibbetings are considered below. However, for the majority of those sentenced to gibbeting at provincial assizes, the three most prevalent concerns when selecting a gibbet location are proximity to scene of crime, visibility from the public road, and the capacity of the immediate locale to cope with a large crowd. Although the second of these is rarely specified in either the sentence or the cravings, a study of the locations of gibbets, where known, demonstrates a close correlation between gibbet sites and proximity to what are now A-roads in Britain. A 1755 travellers' guide to London explains to foreign visitors that gibbets were situated on the highway "near the Place where the Fact was done, to perpetuate the Villainy of the Crime, and to serve as an Example". 8 To be effective as a warning or a deterrent, the gibbet had to be highly visible. But this requirement was sometimes in conflict with the needs of travellers to pass freely without being either inconvenienced by crowds of vulgar spectators or brought into such close contact with the decomposing bodies that delicate sensibilities would be offended. The location of John

\footnotetext{
${ }^{7}$ General Evening Post, 12-15 April 1766 issue 5069.

${ }^{8}$ Anon (1755) London in Miniature (London: C. Corbett), p. 217.
} 
Haines's gibbet on Hounslow Heath, erected in 1799, was criticised in one London newspaper for being "shamefully placed close to the high road", a criticism rejected by another paper, which claimed that in fact "so far from being offensively situated, [it] is placed at the distance of at least five hundred yards from the high road".?

When the gibbet was sited, use was sometimes made of natural features in the landscape that enhanced its visibility. When John Naden was hung in chains in Staffordshire in 1731, his gibbet was erected "on the highest hill on Gun Heath" within a quarter mile of the house where he murdered his master. ${ }^{10}$ Lingard's gibbet near St Peter's rock in the Derbyshire peaks was sited near the main road and close to the tollbooth whose keeper he had murdered. Its visibility from both the scene of crime and the highway more generally was accentuated by taking advantage of a natural local landmark (Fig. 2.1). The roads along which gibbets were located were also, as far as possible, major routes, and the gibbets were close to junctions where they would be noticeable from at least two roads. Ogilby's seventeenth-century linear maps of British journeys show a number of gibbets, marked as waymarks in the same way that prominent windmills or stands of trees are included. Interestingly, when the 1628 gibbet of John Felton, murderer of the Duke of Buckingham, fell down, it was replaced by an obelisk in 1782 - not as a memorial to Felton or the Duke of Buckingham but to serve as a boundary marker as the old Southsea gibbet had come to mark the boundary of the borough of Portsmouth (Fig. 2.2). The obelisk, photographed in the 1930s, has since disappeared. ${ }^{11}$

In this period, however, there is comparatively little evidence of the re-use of archaeological sites for gibbets, in contrast to widespread medieval practice and practice on the continent in early modernity. ${ }^{12}$

${ }^{9}$ Whitehall Evening Post, 12-14 March 1799, issue 8056; Morning Herald, 15 March 1799 , issue 5769.

${ }^{10}$ Daily Courant, 13 September 1731.

${ }^{11}$ www.memorials.inportsmouth.co.uk/southsea/obelisk.htm.

${ }^{12}$ See, for example, H. Williams (2006) Death and Memory in Early Medieval Britain (Cambridge: Cambridge University Press); Andrew Reynolds (2009) Anglo-Saxon deviant burial customs (Oxford: Oxford University Press); J. Coolen (2014) 'Places of justice and awe: the topography of gibbets and gallows in medieval and early modern north-western and Central Europe' World Archaeology 45(5), pp. 762-79. 


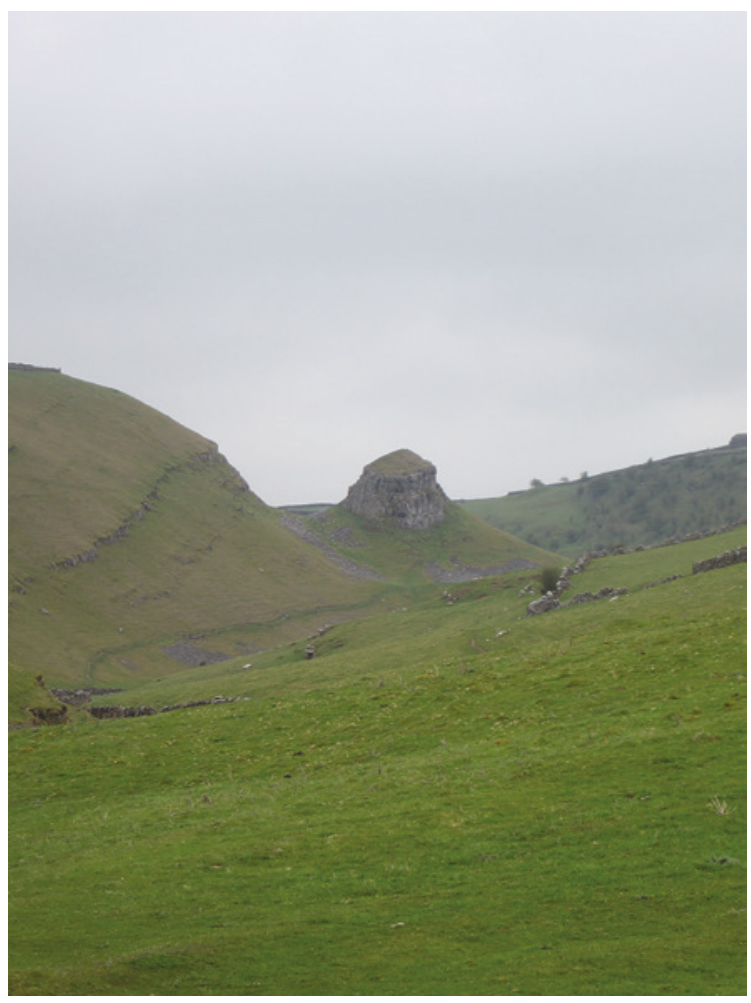

Fig. 2.1 St Peter's rock, Derbyshire, where Anthony Lingard was hung in chains in 1815 (photo: Sarah Tarlow)

John Nichols, whose gibbet cage was excavated in the twentieth century and now is on display in Moyses Hall, Bury St Edmunds, was originally hung in chains on a prehistoric burial mound called Troston Mount at Honington in Suffolk, and Michael Morey's Hump on the Isle of Wight is now named for the murderer gibbeted there in 1737 but is in fact a Bronze Age mound. Combe gibbet, erected in 1676, makes ostentatious use of an earlier monument-the Inkpen neolithic long barrow on Gallows Down-and according to most stories of that double gibbet, it was placed on a parish boundary in order that the costs might be shared 
Fig. 2.2 Felton's obelisk in Portsmouth. (Portsmouth: Charpentier)

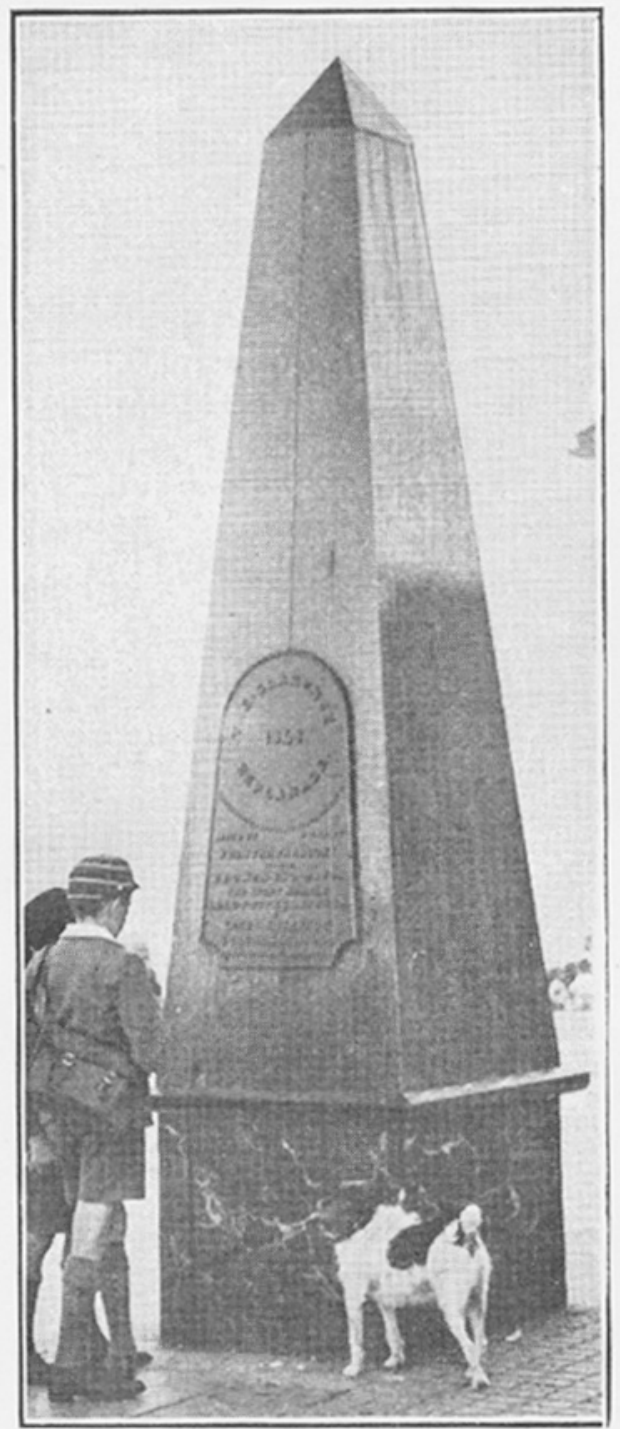

The Obelisk which formerly enclosed the gibbet upon which Felton's body was hung. It also marked the east point of the Portsmouth Boundary 
between the two adjacent parishes to which the two convicted murderers belonged, so the mound's function as a parish boundary marker might be more significant than its archaeological heritage. Whyte suggests in her Norfolk-based study that gibbets were usually sited on or close to parish boundaries, where they crossed open or common land, a location which had a symbolic importance of considerable time depth. She traces the use of boundary points for criminal execution and burial to early medieval beliefs about the liminality of the dangerous and deviant dead, through the traditional use of boundaries for siting gallows by the manorial courts of the later middle ages. Whyte argues that, by the later medieval period, the placement of gallows at parish boundaries "was intended not so much to convey any idea of territorial 'marginality', but rather to denote the eviction of the condemned from the spiritual core of the community-represented in the landscape by the church and the graveyard". ${ }^{13}$ My research has not found the close relationship between gibbet locations and parish boundaries to be so evident elsewhere; the twin principles of siting the gibbet close to a public road and near the scene of crime, however, do produce a gibbeted landscape of marginal landcommons, verges, heaths and forests, which might increase the chances that a gibbet would be sited on or close to a parish boundary. The interpretation that gibbet locations are geographical representations of the criminal's exclusion from normal society is strong and, though probably not the primary determinant of siting the gibbet, undoubtedly added to the force of witnessing it.

The likelihood that large crowds of people would attend the gibbeting militated towards the selection of open or common land as gibbet sites, but on other occasions private land was used. The sheriffs' cravings for Devon in 1752 note a cost incurred "for an express to go to Mr. Wiscotts about 40 miles to ask leave to erect a gibbet on his manor in order to hang up the body of John Young (not receiving the order for so doing til he was executed)".

As conspicuous locations in public places, gibbets acted as meeting points and landmarks. Jeremiah Abershaw's gibbet on Putney Heath is mentioned in the press as the location of a boxing match in 1796 and 1800, a duel in 1798, and a military tattoo in 1803. In 1773, at Kennington Common

\footnotetext{
${ }^{13} \mathrm{~N}$. Whyte (2003) 'The deviant dead in the Norfolk landscape' Landscapes 1, p. 35.
} 
Several gentlemen, frequenters of a very genteel public house not far from Duke's Court, Bow Street, Covent Garden, intend in a few days to decide a wager depending on a game at Trap Ball on Kennington Common in a very whimsical and humorous manner; three fourths of the party being either old, lame with gout corns or other inflammations affecting feet and legs, while the rest are young, nimble and alert, have unanimously agreed to play the game each person in a wheel barrow, which is managed by the strongest and most fore footed Irish chairman anywhere to be found. As this expedient puts all parties on equality, it is expected there will be much sport and fair play unless charioteers should be bribed to jockey one another. The parties to rendezvous as near the gibbets as possible. ${ }^{14}$

One of the remarkable features of gibbet locations is the apparent irrelevance of buildings or monuments that signify State power. Laqueur has noted that many eighteenth- and nineteenth-century executions did not take place close to the civic or judicial apparatus of State or local authority but rather customarily used a suburban location of little distinction. ${ }^{15}$ Similarly, the places where the body was fixed for display were very rarely in urban locations and were usually far from any building or monument meaningful to the working of the institutions of State, although they were rarely far from roads.

Proximity to the scene of crime often also resulted in proximity to the home of the criminal, although there is no evidence that gibbets were deliberately sited to be close to the home of either the criminal or the victim. Such siting, however, could have harsh consequences for the family of the gibbeted man. Not only would they be confronted regularly with the horrible spectacle of the body of their relative in the process of decay which would be emotionally upsetting, their friends and neighbours would also be constantly reminded of the evil done by their kin. This was the reason that Thomas Willdey's family petitioned the sheriff in 1734 asking for his body to be removed from its site on Witley Common near Coventry: the innocent and respectable members of the family were subject to comment, abuse and loss of trade in their local

\footnotetext{
${ }^{14}$ Middlesex Journal or Universal Evening Post, 22-24 July 1773, issue 674.

${ }^{15} \mathrm{~T}$. Laqueur (1989) 'Crowds, carnivals and the State in English executions, 16041868', in A.L. Beier, D. Cannadine, J.M. Rosenheim (eds.) The First Modern Society (Cambridge: Cambridge University Press), pp. 305-55, p. 312.
} 
area by reason of the continuing presence of Willdey's "offensive" body. ${ }^{16}$ Thomas Jackson, convicted of robbing the mail, was hung in chains on Methwold common "near the place where he committed the robbery", which was "directly opposite to the dwelling of his unfortunate family". ${ }^{17}$ In 1797, an estate map of the village of Nether (or Lower) Hambleton in Rutland, now drowned beneath Rutland Water, annotated one cottage with a cross and the note "where you never gomother to the young men that were hanged". ${ }^{18}$ The young men in question were the Weldon brothers, gibbeted for murder within sight of their parents' cottage. One can only imagine the difficulties of living on in a small community and enduring every day the sight of your sons' dead bodies, as well as what sounds like ostracism by your neighbours.

\section{Hanging at the Scene of Crime}

Gibbets were usually erected for the display of the dead body only; the criminal had actually died on a scaffold constructed at the customary place of execution for that town.

Steve Poole has studied the incidence of scene-of-crime executions in Britain. ${ }^{19}$ Between 1720 and 1830, at least 211 people were hanged on specially erected scaffolds at the scene of their crime. More than half of these crime-scene hangings took place in the southeast (London and Surrey) and in Gloucestershire and Somerset. Most of those executed at the scene of crime were taken down and disposed of elsewhere, but a minority were subsequently enclosed in gibbet cages and then hung up again on the same framework. Poole suggests that although the sheriff

\footnotetext{
${ }^{16}$ TNA SP $36 / 32 / 115$.

${ }^{17}$ London Chronicle, 1-3 April 1790, issue 5244; Public Advertiser, 17 April 1790, issue 17403.

${ }^{18}$ S. Sleath and R. Ovens (2007) 'Lower Hambleton in 1797', in R. Ovens and S. Sleath (eds.) The Heritage of Rutland Water (Rutland Record Series number 5 ) Oakham: Rutland Local History and Record Society, pp. 193-209.

${ }^{19}$ Steve Poole (2015) 'For the Benefit of Example': Crime-Scene Executions in England, 1720-1830', in R. Ward (ed.) A Global History of Execution and the Criminal Corpse. Basingstoke: Palgrave: 71-101; Steve Poole (2008) 'A lasting and salutary warning': incendiarism, rural order and England's last scene of crime execution', Rural History 19, pp. 163-77.
} 
rarely made explicit the reason for holding an execution at the scene of the crime instead of in the customary location, crimes of brutal murder and crimes involving foreigners or where there was a high risk of crowd disorder were most likely to be singled out in this way. Scene-of-crime executions were highly personalised and related with a pleasing symmetry to the crime, which might have helped to satisfy the popular appetite for balanced revenge. ${ }^{20}$ Demonstrations of State power in out-of-theway spots also helped, argues Poole, to re-establish local authority in isolated rural areas. Contemporary commentators were also impressed by the sentimental potential of the malefactor's last moments incorporating a view of his childhood haunts and the place of his undoing. A powerful dramatic experience such as a scaffold confession or visible moment of contrition would be more readily provoked and make a more emotionally powerful impression in this highly theatrical setting.

\section{Gibbets in the Landscape}

The presence of a gibbet could change the experience of a local landscape for a long time after its erection, even to the present day. The large crowds and carnival atmosphere of the newly erected gibbet would continue for only a few weeks, but the memory of the unusual event would last a lifetime for those who had been present. Moreover, the gibbet itself often remained standing for many decades and would affect both the experience of travelling through the landscape and the way in which the landscape was known. Gibbet locations and former gibbet locations acted as landmarks. The inclusion of eight gibbets on Faden's 1797 map of Norfolk demonstrates that the gibbets were important landmarks. Earlier national maps, such as Ogilby's Britannia of 1675, show several gibbets along with windmills, bridges and other fixed points by which the progress of a road journey would be marked.

A gibbet might remain in place for many decades. Since they were often ten metres or more in height, they were conspicuous in the landscape and affected the way that local people knew and experienced the area, through giving new names to the roads and fields where they were sited, and by giving emotional impact to local journeys, or even motivating the creation of new routes. Ralph's Lane and Tom Otter's Lane in Lincolnshire, Old

\footnotetext{
${ }^{20}$ Public discussion at the time of the Murder Act included a number of voices in favour of some sort of lex talionis-a punishment regime which mirrors the nature of the crime.
} 


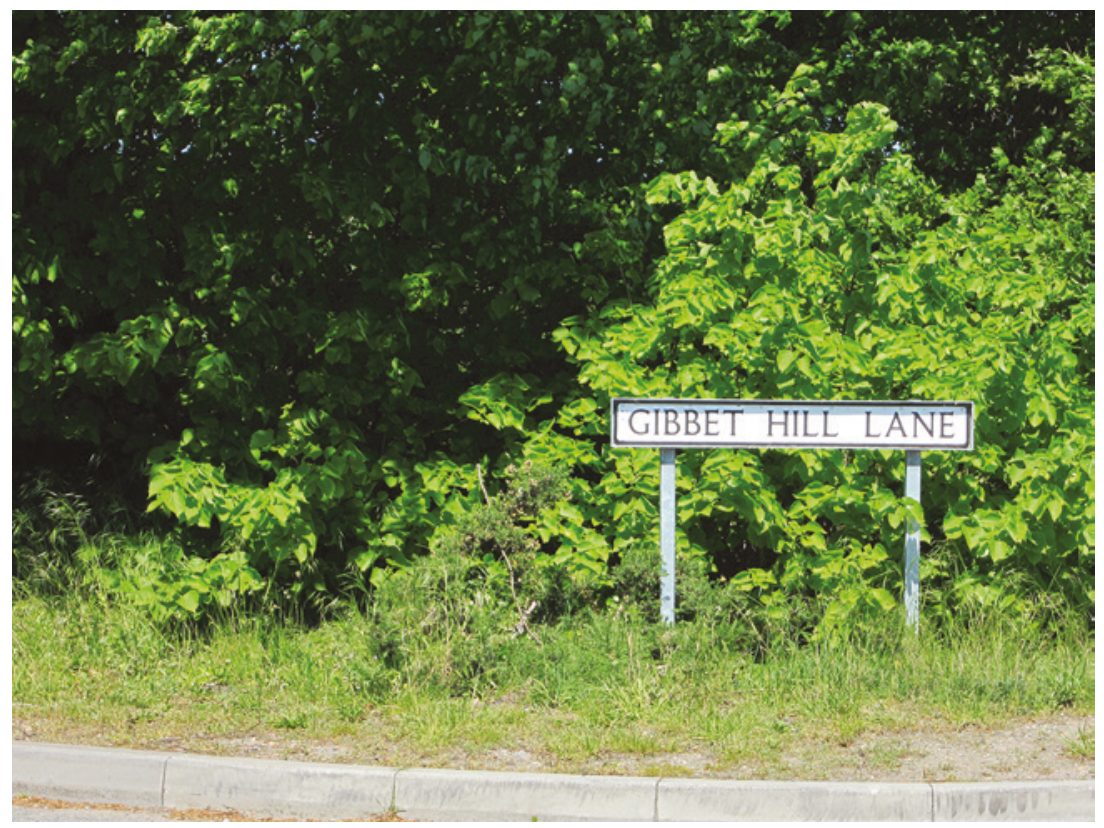

Fig. 2.3 Road sign, Gibbet Hill Lane, Scrooby (photo: Sarah Tarlow)

Parr Road in Banbury and Curry's Point near Whitley Bay are among the places named after the criminals who were gibbeted there. The numerous instances of 'Gibbet Woods', 'Gibbet Hill' and 'Gibbet Lane' in England are hard to date and in most cases are probably medieval in origin, but a number of those are associated with known eighteenth-century gibbets, such as the Gibbet Hill Lane at Scrooby, close to the 1779 gibbet of John Spencer (Fig. 2.3). What was it like to travel through a landscape populated with the remains of the dead? Sources suggest that, for most people who lived close to these structures or encountered them regularly, it was at best distasteful and often quite horrifying and that people would take measures to avoid passing a gibbet when possible, especially at night. A report in the Buckinghamshire archives notes that

“the footpath running from 'Chalkhouse Arms' and continuing back along the back of the hovels in Bierton, as far as 'the milestone' dates from this execution, and was made in order to avoid passing the gibbet 
[of Corbett, d. 1773]". ${ }^{21}$ W.H.B. Sanders ${ }^{22}$ says that the former ostler at a nearby inn recalled seeing Gervase Matcham's gibbet on rough ground adjacent to the Great North Road:

It often used to frit me as a lad. I have seen horses frit with it. The coach and carriage people were always on the look out for it. Oh yes! I can remember it rotting away, bit by bit, and the red rags flapping from it. After a while they took it down and very pleased I were to see the last of it.

The ostler's revulsion was shared by the young Charlotte Latham, who remembered the full sensory assault of having to pass a gibbet on the Brighton Road in her childhood: "Standing on the wide desolate down, with all its fearful associations, it was an object of great terror to me in my youthful days; and the dread of seeing it and hearing my nurse repeat her oft-told tale of the murderer who had been hung on it in chains, and how he had been swinging on a windy night and heard rattling his irons, made the prospect of a visit to the sea-side, which involved the sight of the gallows anything but pleasurable". ${ }^{23}$

Wordsworth famously remembered his encounter with the site of Thomas Nicholson's gibbet at Penrith. Nicholson had been gibbeted in 1767, and by the time Wordsworth came to the spot

"The gibbet-mast had mouldered down, the bones

And iron case were gone". ${ }^{24}$

However, as Duncan Wu notes, if Wordsworth is reminiscing about the year 1775, the gibbet mast would not have mouldered down and indeed a five-year-old child would probably not have ridden so far unaccompanied. Wu suggests that another Cumbrian gibbet may have been intended. ${ }^{25}$ Whatever the case, The Prelude is not an accurate historical record but, for our present purposes, a good indicator of the response of a sensitive Romantic spirit to the presence of gibbets in the landscape: Wordsworth "fled/Faltering and fain, and Ignorant of the road".

\footnotetext{
${ }^{21}$ From a letter dated April 18 1860, signed by J. Wharton to Rev. C. Lowndes. At http://myweb.tiscali.co.uk/corbettonenamestudy/First/Books/Extract2.htm.

${ }^{22}$ W.H.B. Sanders (1887) Legends and traditions of Huntingdon (London: Simpkin, Marshall and Co.), pp. 103-04.

${ }^{23}$ Charlotte Latham (1868) Some West Sussex superstitions lingering in 1868, collected by Charlotte Latham at Fittleworth (London: The Folk-Lore Society).

${ }^{24} \mathrm{~W}$. Wordsworth The Prelude 1805 version 11: lines 290-01; lines 299-300.

${ }^{25}$ D. Wu (2002) Wordsworth: An Inner Life (Oxford: Blackwell), p. 465.
} 
When Mary Hardy, a Norfolk farmer's wife, visited North Yorkshire, she made a special trip to see the gibbet of Eugene Aram in Knaresborough 16 years after it had been erected there. ${ }^{26}$

\section{Out of the Ordinary}

Most gibbets were erected in rural areas by county sheriffs in direct response to an assize court judgement of a single person. There were, however, two variants of hanging in chains which followed different customs-those in London and those carried out by the Admiralty courts. Let us look briefly at both.

\section{Exception 1: London}

London was an exceptional city throughout the period of study, as it has been throughout post-Roman British history and as it remains today. Those convicted of a capital offence in London were more likely to die than those convicted elsewhere in Britain (where pardons were common or a non-capital sentence was substituted). ${ }^{27}$ Although London had only $10 \%$ of the population, it produced $30 \%$ of the executed bodies. This exceptionalism also affected the location of London gibbets. Whereas in most of Britain gibbets were erected for their proximity to the scene of crime and for visibility from the main road, those sentenced to hanging in chains in the metropolis were not put close to the place of their crimes but in one of a small number of traditional gibbet locations. These were usually pieces of open land just outside the city but adjacent to one of the main roads in and out of London. Finchley Common, Hounslow Heath, Bow Common and Shepherd's Bush were all areas used for several gibbets, and a number of others were erected along the Edgeware Road. Although these locations did not relate to the details of the crime or indeed to the criminal's biography in any way, they were well chosen for public visibility and, for the most part, permitted the formation of large gibbet crowds without threatening public order. The reason for siting London gibbets on one of a few regularly used open locations rather

\footnotetext{
${ }^{26}$ Mary Hardy's Diary (ed. B. Cozens-Hardy). 1938. Norfolk Record Society Vol. 37.

${ }^{27}$ P. King and R. Ward (2016) 'Rethinking the Bloody Code in Eighteenth-Centre Britain: Capital Punishment at the Centre and on the Periphery' Past and Present (2016).
} 
than at the scene of crime is not discursively addressed in contemporary literature, but it is likely that the dense urban landscape in which most of the crimes took place was impractical for erecting gibbets. Although the streets and squares of London hosted various carnivals, markets and events, these were ephemeral events. Gibbets normally remained standing for decades. The large crowds drawn to a gibbeting could not be accommodated in an orderly way in the narrow roads of the capital, where traffic would be stopped and the risk of public disorder was always high. Moreover, the continuing presence of a rotting corpse among the dense habitations of the living would surely have been considered unpleasant even before the hygienic reforms of the mid-nineteenth century would have condemned it as unsanitary. Early nineteenth-century reformers campaigning for the closure of overfull urban graveyards emphatically condemned the proximity of dead bodies to the places of the living. The 'miasmas' of infection produced by the decaying body had injurious or fatal consequences for the health of the living. ${ }^{28}$

\section{Exception 2: The Admiralty Courts and Maritime Crimes}

In addition to those criminals who passed through the normal assize or London courts, at least 87 men were sentenced to death by the Admiralty courts between 1726 and 1830, and the records of the Admiralty court enable some analysis of this group (Table 2.2). The Admiralty courts dealt with crimes committed at sea and were mostly for murder at sea or piracy. Mutiny, theft and sinking or destroying a ship also resulted in a small number of capital convictions. Of these 87 men, at least 38 were gibbeted, at least 3 were dissected, 6 were interred without further punishment, 3 had their sentences commuted to transportation, one was rescued from the scaffold, and the fate of the others is unknown, although most of them were sentenced to dissection. We have not been able to trace the ultimate fate of some of those sentenced. Even if we assume that none of those whose ultimate fate is unknown was gibbeted, 38 out of 87 is a very high proportion-much higher than the proportion of murderers sentenced to be hung in chains by the terrestrial courts. Hanging in chains for those convicted by the Admiralty Court was distinctive in a number of ways. First, the Admiralty courts made repeated use of customary locations for both execution and gibbeting. Most executions were

\footnotetext{
${ }^{28}$ See, for example, G. Walker (1839) Gatherings from Graveyards (London: Longman).
} 


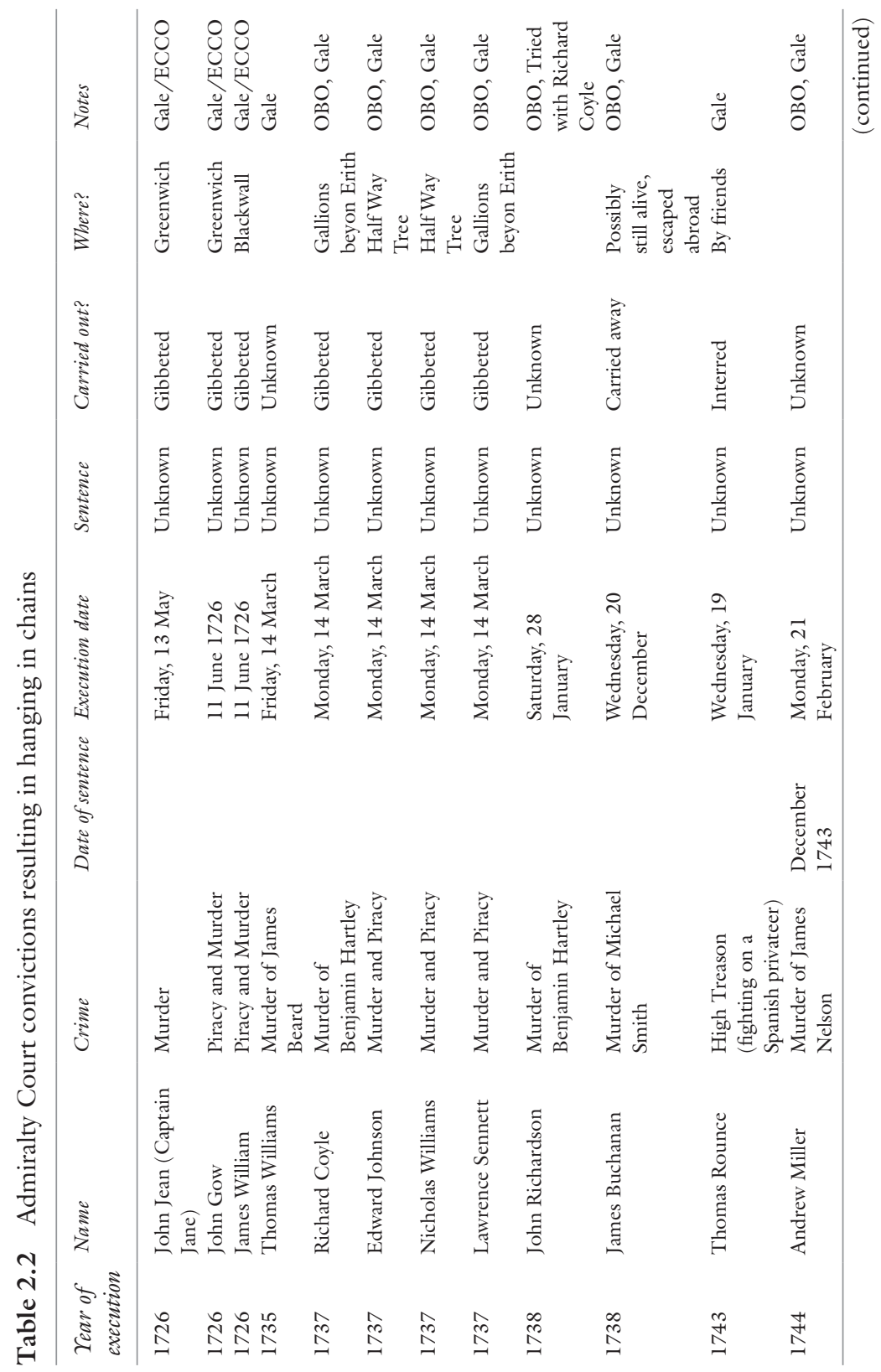




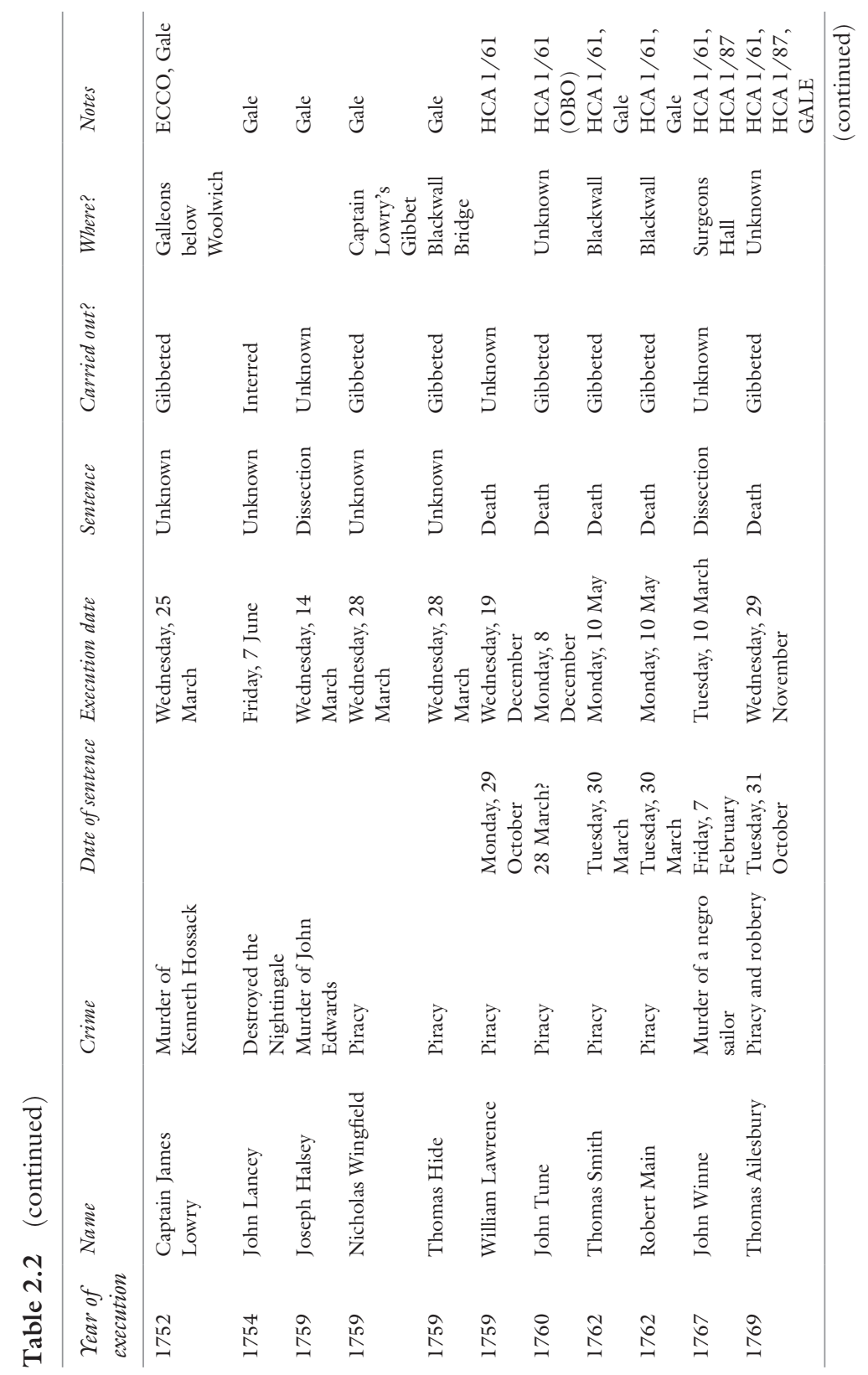




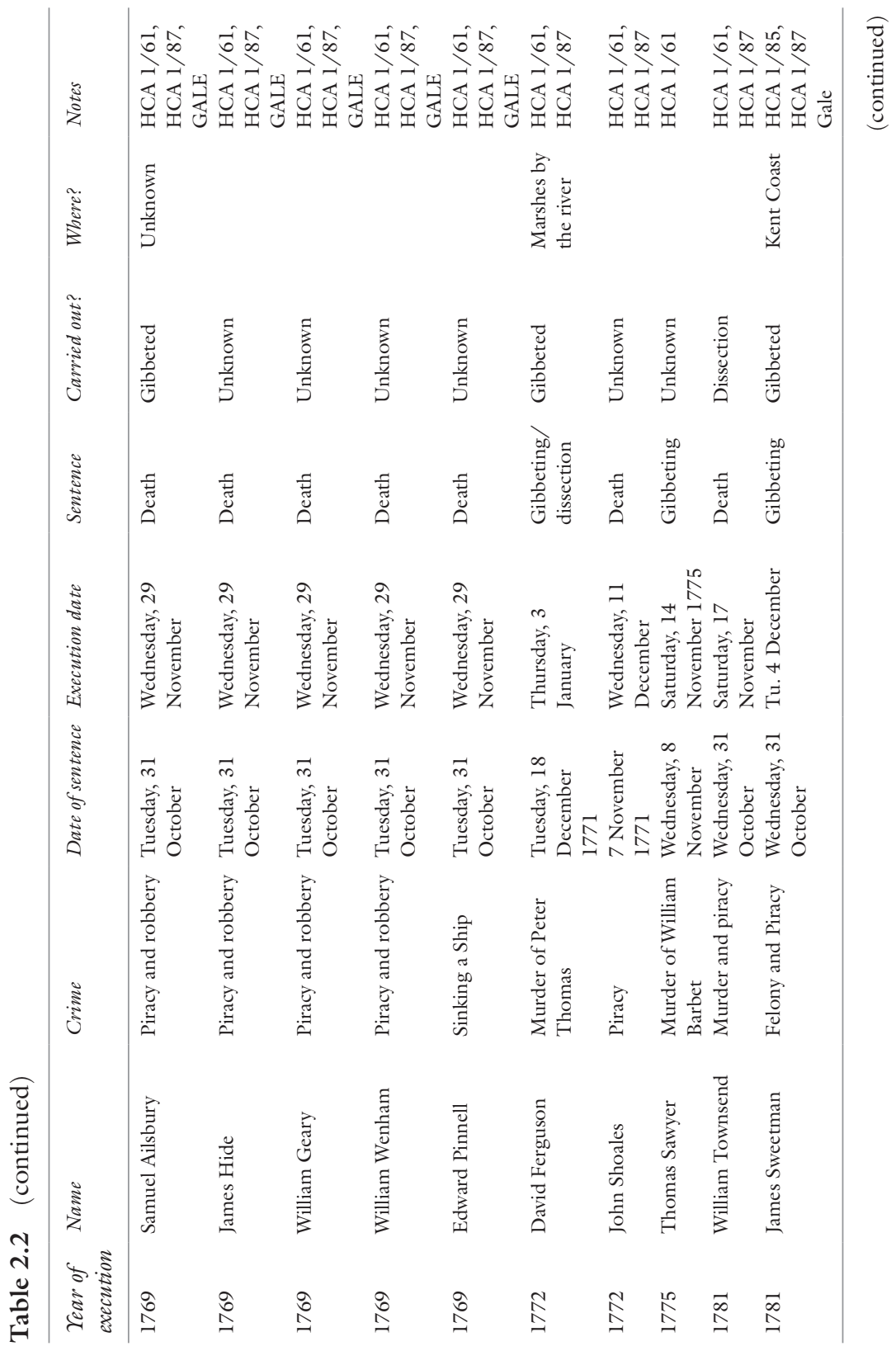




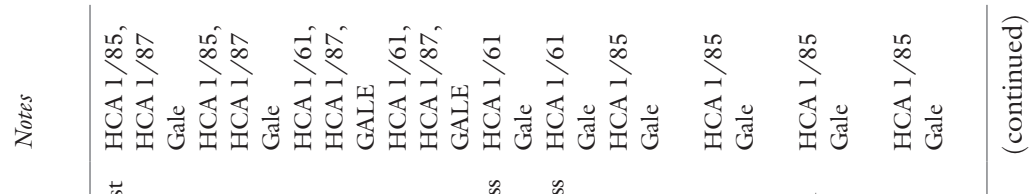

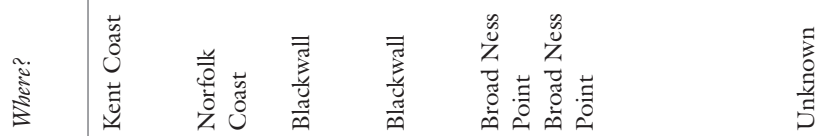

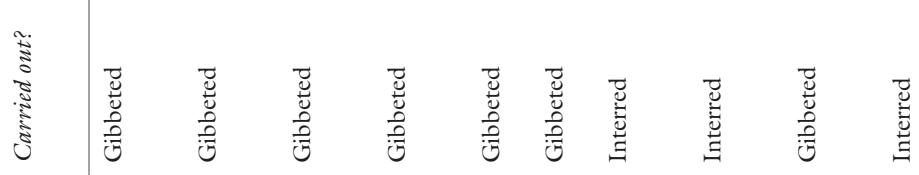

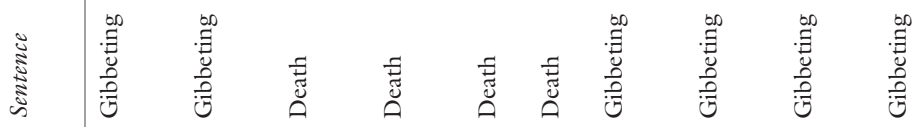

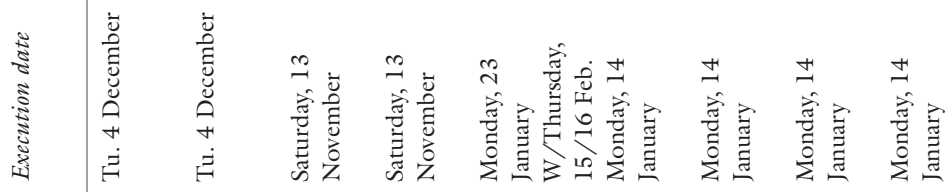

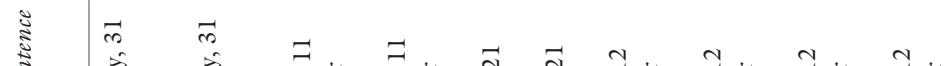

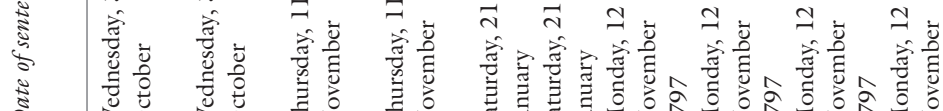

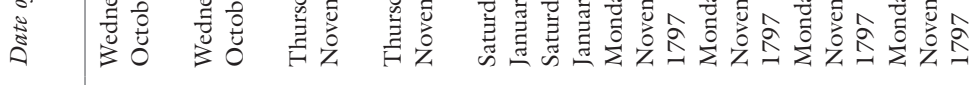

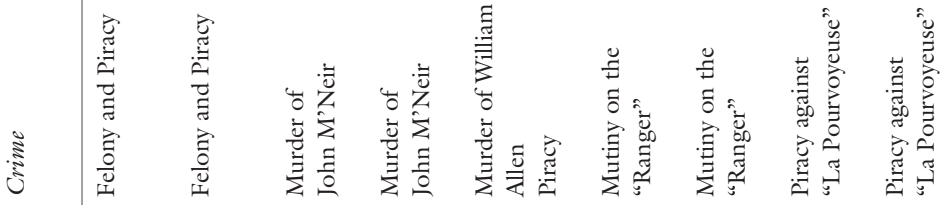

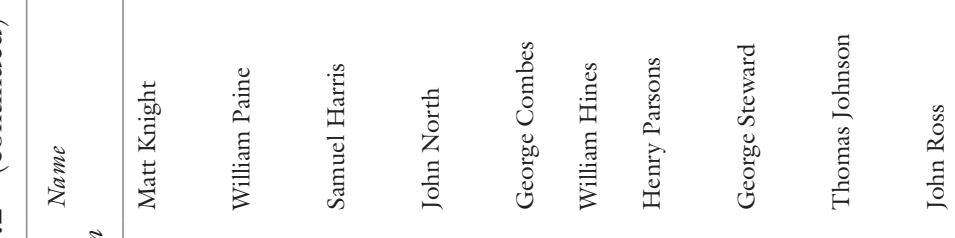

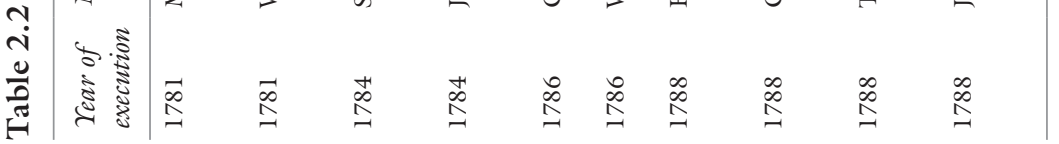




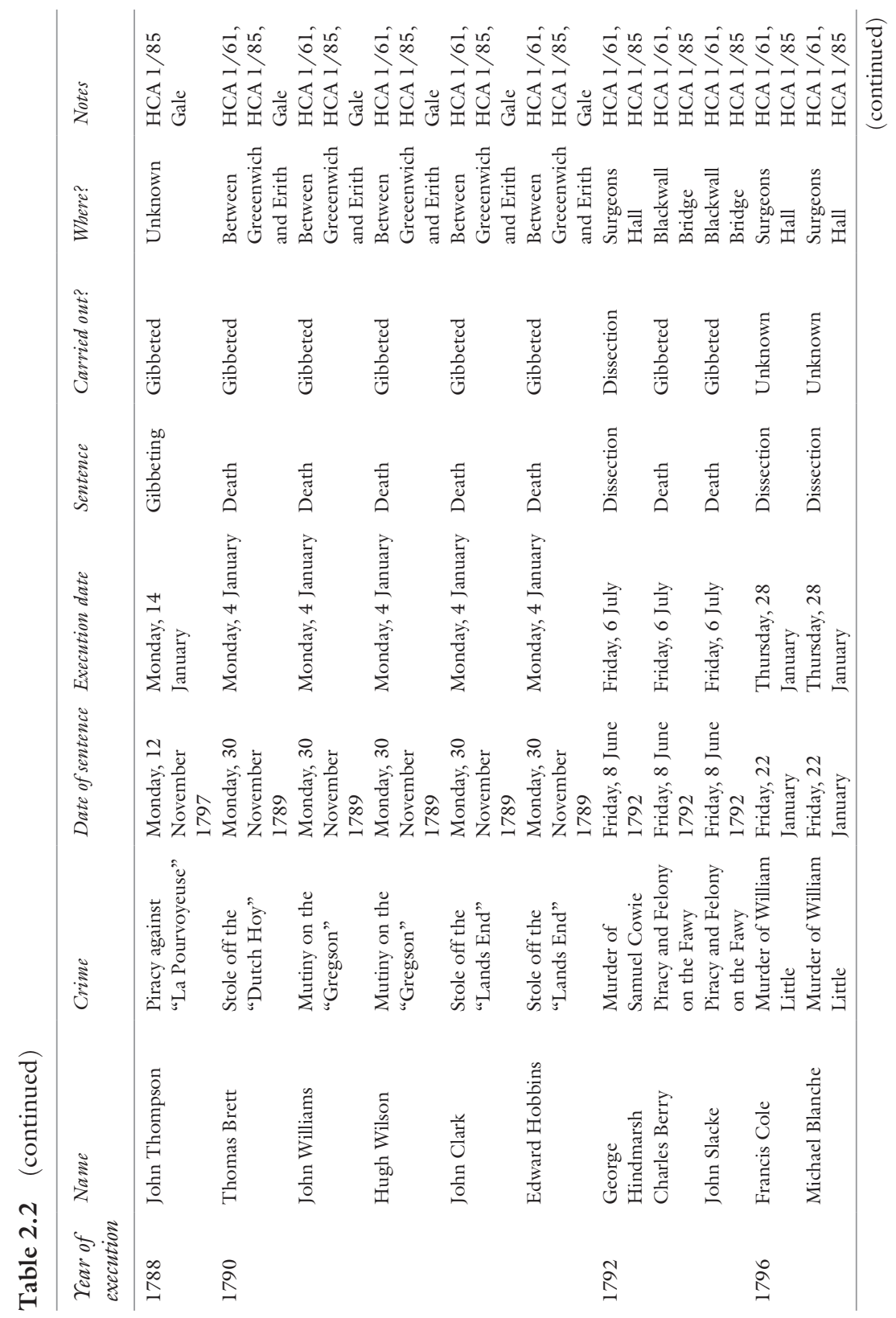




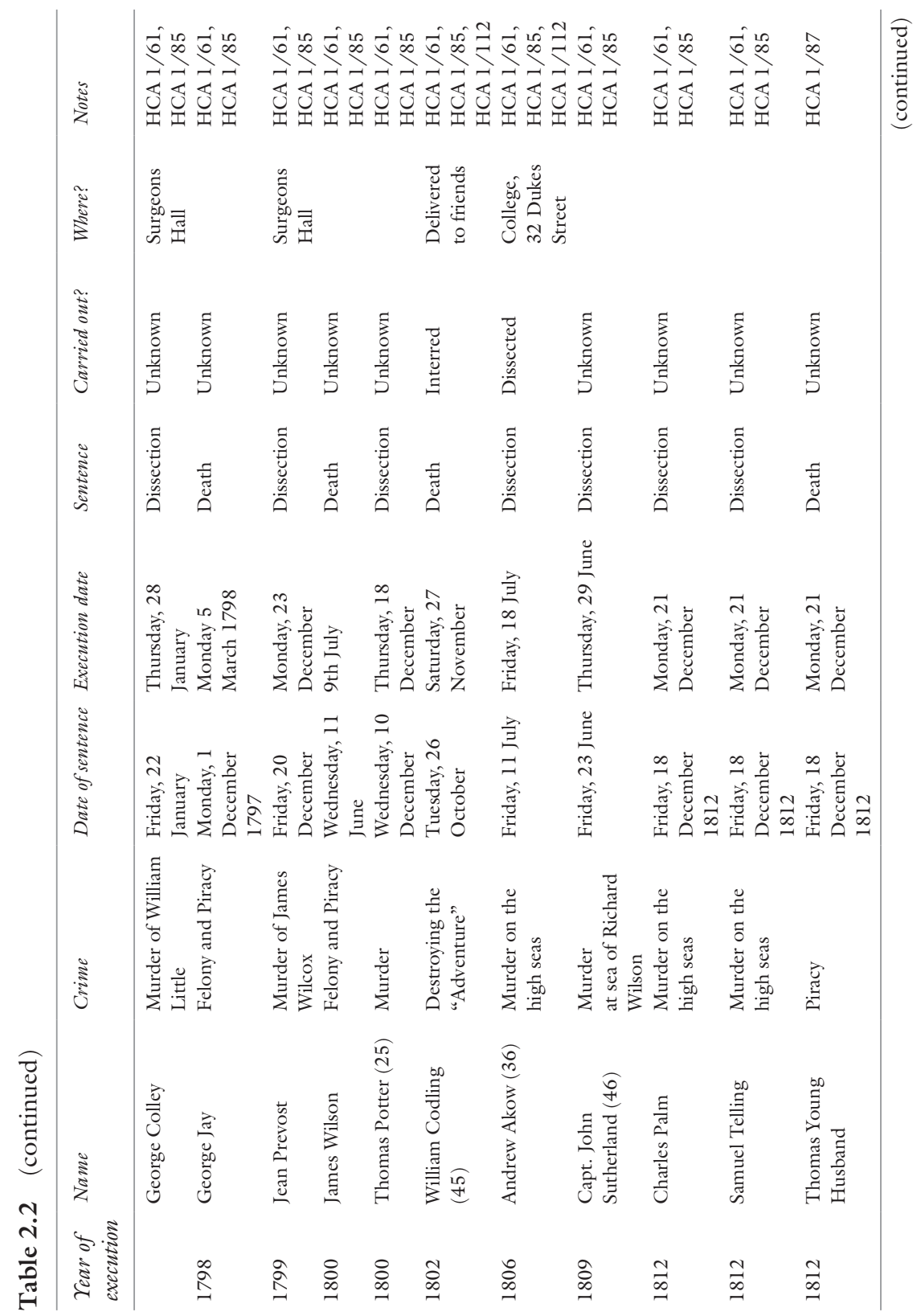




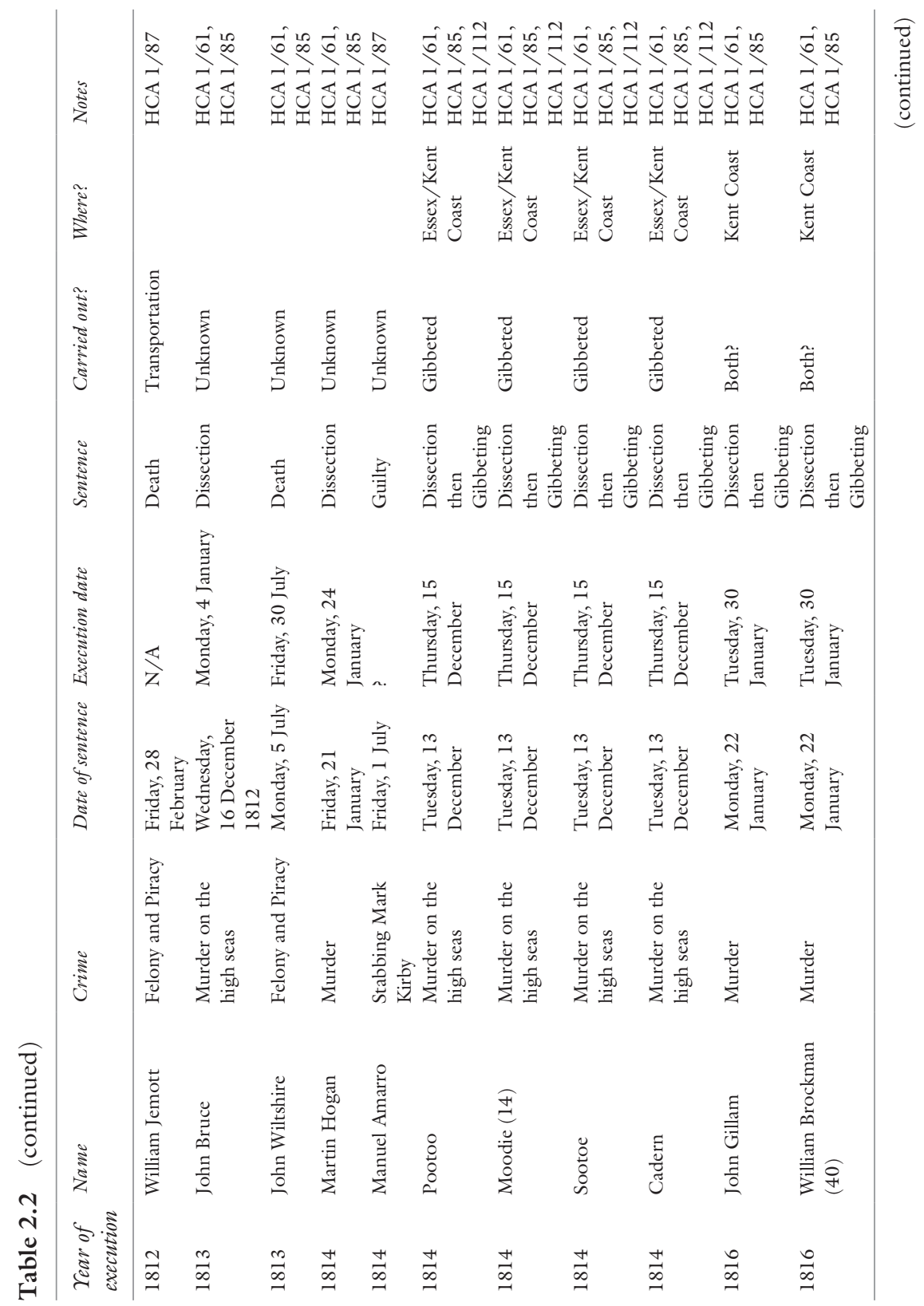




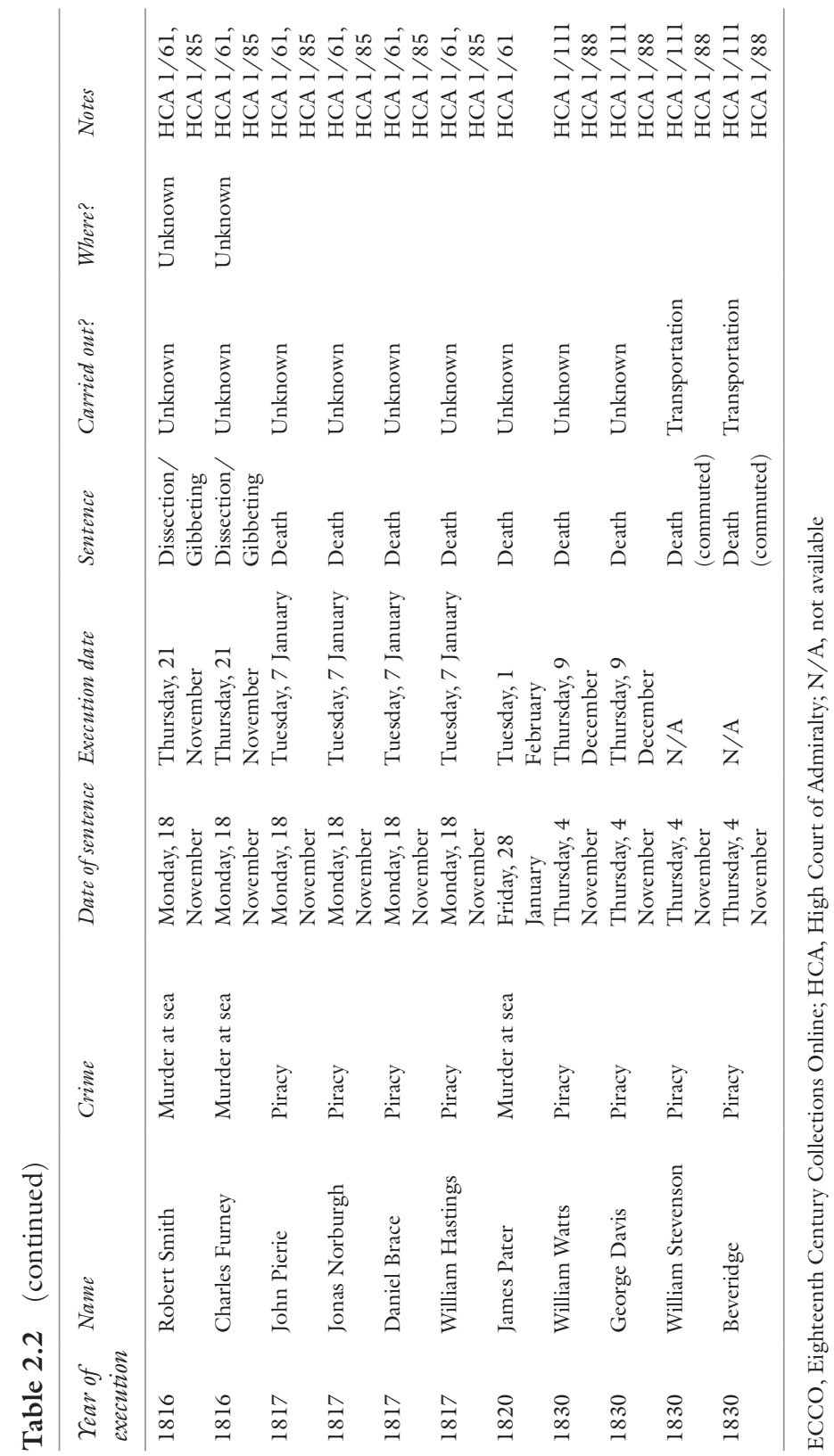


carried out in London at Execution Dock, and the body then was moved to a suitable place for display in a gibbet. The account of Captain James Lowry's execution in 1752 mentions that his body was conveyed by boat from the scaffold at execution dock to 'The Galleons' (Galleons Reach and Galleons Point are locations on the Thames, north of Woolwich) where he was to be hung in chains. ${ }^{29}$ Some accounts record that Lowry's body was later stolen from his gibbet. Earlier in the eighteenth century, the famous pirates Gow and Williams had been executed in 1726 at Execution Dock and their bodies subsequently displayed at Gray's and Blackwall, also locations along the Thames.

By custom, all those sentenced to death by the Admiralty courts were hanged at Execution Dock in Wapping. Following execution, bodies were traditionally chained to a stake at low water until three tides had washed over them, although this practice had apparently died out by the late eighteenth century. ${ }^{30}$ Only after this water ritual were those who were eventually to hang in chains taken from Wapping to a location further down the Thames and gibbeted in a place that would be conspicuous to all river traffic entering or leaving London on the east. Those sentenced to dissection were apparently subjected to a scaled-down version of the three-tides punishment and left only until the water touched their toes before being taken to the surgeons, presumably so that the body was not spoiled by time or bloating.

William Clift, of the Royal College of Surgeons, himself painted the scene of an Admiralty execution in 1816. The watercolour shows huge crowds assembled on the Thames foreshore and on boats anchored in the river, watching two figures on a scaffold. Interestingly, the scaffold itself is erected well below the high water mark, and it looks as though it would be possible for the bodies executed there to remain on their scaffold for three high tides without being taken down and restaked in the river. It is also clear that it would make no sense at all to take the bodies down only in order to dip their feet in the water, when a couple of hours of waiting

\footnotetext{
${ }^{29}$ The Monthly Chronologer. London Magazine, March 1752, p. 145.

${ }^{30} \mathrm{~T}$. Pennant London; or an abridgement of the celebrated Mr Pennant's description of the British capital and its environs (London, 1790), p. 157: "The criminals are to this day executed on a temporary gallows, placed at low water mark; but the custom of leaving the body to be overflowed by three tides, has long since been omitted".
} 
would bring the river to their ankles anyway. This accords closely with Pennant's description of the gallows "placed at low water mark". ${ }^{31}$

Smuggling was not a crime that was normally tried by the Admiralty courts; instead, it usually came to ordinary assize courts or the Old Bailey. Dyndor's study of the location of the gibbets of the notorious Hawkhurst gang of smugglers in Sussex and Kent notes that unlike most murderers' gibbets outside London, the men's gibbets were not sited at places of particular significance in relation to the crimes for which they were convicted. Instead, prominence seems to have been a key factor, and gibbets were sited on topographical eminences such as Rook's Hill or Selsey Bill or by main roads. In East Sussex, the gibbets were more likely to be sited close to the villages from which the criminals came. ${ }^{32}$

\section{Liminality: The Symbolic Location of Gibbets}

Archaeological studies of unusual burials, such as the deposition of bodies in bogs in northern Europe from the Iron Age to the medieval period, have often suggested that these burials are the remains of criminals whose deviancy is signalled in non-normative burial rites. ${ }^{33} \mathrm{~A}$ key aspect of these interpretations is that the places of disposal of deviant dead are liminal-boglands that are neither wet nor dry; foreshores that are neither sea nor land. Similarly symbolic interpretations of later historical periods are not so common, but there is certainly an argument to be made that gibbeting the criminal body symbolises its liminality and that the enduring nature of the gibbeting process keeps it literally suspended

\footnotetext{
${ }^{31}$ Pennant, London, p. 157; Anon. (1761) London and its environs described (London: R. and J. Dodsley), p. 289. The copyright holder refused permission to publish this image here.

${ }^{32}$ Zoe Dyndor (2015) 'The Gibbet in the Landscape: locating the criminal corpse in mid-eighteenth-century England', in R. Ward (ed.) A global History of Execution and the Criminal Corpse (Basingstoke: Palgrave).

${ }^{33}$ For bog bodies, see R.C. Turner and R. G. Scaife (1995) Bog Bodies: new discoveries and new perspectives (London: British Museum Press); P.V. Glob (1965) The Bog People: Iron-age man preserved. Trans. Rupert Bruce-Mitford (New York: Barnes and Noble). For liminality in other forms of prehistoric burial, see Liv Nilsson Stutz (2014) 'Mortuary practices' in V. Cummings, P. Jordan and M. Zvelebil (eds.) The Oxford Handbook of the Archaeology and Anthropology of Hunter-Gatherers (Oxford: Oxford University Press), pp. 712-28.
} 
between worlds. It is neither buried nor alive; neither human nor thing; and on occasions its landscape positioning also emphasises its liminality. It is not at a place, but by a road. In the case of shoreline gibbets and Admiralty courts, it is at the boundary of land and sea. Whyte and Coolen have both suggested that gibbets occur preferentially at parish or other administrative boundaries. ${ }^{34}$

\section{Technology of The GibBet}

Once a suitable location was identified, the erection of the gibbet scaffold and the suspension of the gibbet cage had to take place swiftly. This was not always easy. The Somerset sheriffs' cravings mention two occasions - in 1739 and 1746-when it was necessary to make holes in the hard rock in order to erect the gibbet pole. ${ }^{35}$

The sheriff was responsible for arranging the erection of a gibbet pole and for the manufacture of a gibbet cage and whatever hooks, chains or other tackle were necessary to suspend the cage. In addition, a pulley or temporary scaffolding would be needed to hoist the heavy iron contraption into position and secure it. In normal provincial practice, gibbets were made for a single criminal and were not normally re-used. ${ }^{36}$ Since a gibbeted criminal would be exhibited close to the scene of crime and could remain in his gibbet for many decades, re-use was not normally practical. The sheriff also had to arrange to transport the body from its place of execution to the gibbet site and to organise security if the journey or the process was likely to attract unruly crowds.

\footnotetext{
${ }^{34} \mathrm{~J}$. Coolen (2014) 'Places of justice and awe: the topography of gibbets and gallows in medieval and early modern north-western and Central Europe' World Archaeology 45(5), pp. 762-79; Whyte 'The deviant dead in the Norfolk landscape'.

${ }^{35}$ Somerset Sheriffs' Cravings (TNA T90/147/307 Stiling; T64/262 Williams and Calway).

${ }^{36}$ However, the gibbet irons in the London Docklands museum, which are not securely provenanced but are likely to come from the riverside area and thus to relate to the Admiralty courts, show two different styles of workmanship. The fact that this cage has apparently been repaired suggests that it might have been re-used. It is possible that re-use was normal for Admiralty gibbets. The other evidence for hanging chains by the Admiralty courts is an image reproduced in Hartshorne, p. 77, showing a very skimpy rig: a simple gusseted chain with a neck brace that would not have secured a body for very long at all. The re-used gibbet and the basic chain are both exceptional designs and might relate to the brief periods of hanging in chains practised by the Admiralty.
} 
Typically, the body of a criminal was gibbeted within a day or two of being executed, but sometimes there were longer intervals, especially when the body had to be transported some distance to the place appointed for gibbeting. Pirates, for example, were usually hanged at execution dock in London but might then be transported many miles around the coast-to Devon or Norfolk, say-to be gibbeted. Occasionally, the judge recognised the time needed to prepare for a gibbeting. Thomas Nicholson, sentenced to execution and hanging in chains at Cumberland Assizes on 22 August 1767, had the date of his execution respited until 31 August in order to make the necessary preparations. ${ }^{37}$ Even so, that gave only just over a week to have the gibbet irons made, a gibbet structure created and erected, and a location prepared. Of the 38 cases for which the date of hanging in chains is explicitly stated in the records, 33 were gibbeted on the day of their execution. The other five executions took place between one and four days before gibbeting, and all except one of these five were transported at least 26 miles from the place of execution to the place of gibbeting, so the delay probably is caused by the need to transport the body to the site where the gibbet was erected. Where no separate date for gibbeting is given, as in the majority of cases, it is probable that gibbeting most frequently occurred on the day of execution (Table 2.3).

The Murder Act specifies that capital sentences for murder should be carried out on the second day after conviction. A short interval between sentencing and execution was considered important as a means of increasing the dreadfulness of the punishment and thus its effectiveness as a deterrent and of reducing the occurrence of last-minute pardons, or at least the hope of a last-minute pardon. Henry Fielding believed the great drawback of a long delay between sentencing and execution was that the atrocity of the crime was less raw in the public mind and likely to be overshadowed by the dreadfulness of the punishment. ${ }^{38}$ Since the date of conviction is not always known, I have for the purposes of Fig. 2.4 calculated the interval between the first day of the assizes during

\footnotetext{
${ }^{37}$ Assize Calendar Cumberland TNA E389/244/26, 26 August 1767.

${ }^{38}$ G. R. Swanson 1990. "Henry Fielding and "a certain wooden edifice" called the gallows', in W.B. Thesing (ed.) Executions and the British experience from the 17th to the 20th century (Jefferson NC: McFarland and Co), 45-57.
} 


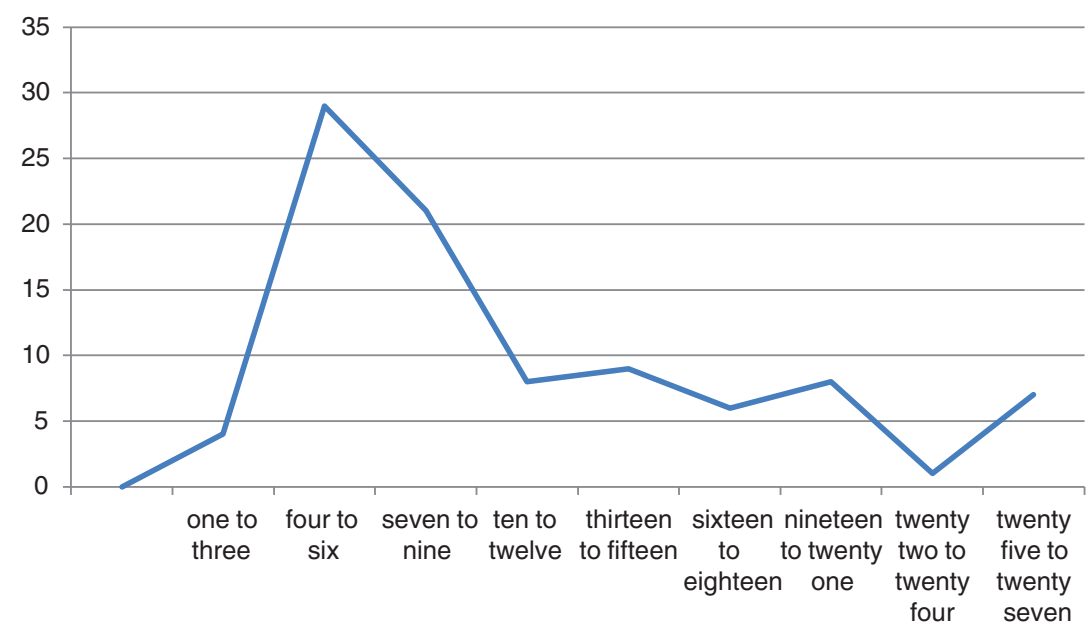

Fig. 2.4 Interval in days between the first day of the assizes during which a criminal was convicted and the date of his execution

which a criminal was convicted and the date of his execution. Among 101 cases in England outside London recorded in the sheriffs' cravings, the mean interval was 10.71 days, although there was considerable variation around this (Fig. 2.4). The Berkshire assizes at which Abraham Tull and William Hawkins were condemned began on 7 March 1787 and they were executed and gibbeted on the 9th-only two days later, or even one day if their case was not heard on the first day of the assize sitting. Thomas Colley, on the other hand, was tried at the Hertfordshire assizes beginning on 29 July 1751 but not executed and gibbeted until 24 August, nearly a month later. Delays of more than two weeks, however, are uncommon. Given that the start of assizes is likely to be before the date of conviction in many cases (assize sittings could take up to a week in this period), we can assume that the blacksmith would normally have a week or less to make a set of irons.

It was necessary therefore to start on the construction of a gibbet and a set of irons as soon as possible after a sentence had been passed. Where possible, the condemned man was measured for his set of irons before execution, a harrowing experience. When Ralph Smith of Lincolnshire was being measured for his irons in 1792, for example, he found it 
Table 2.3 Surviving gibbet cages

\begin{tabular}{|c|c|c|c|}
\hline Date & Name & County & Present location \\
\hline $1720 ?$ & Siôn Y Gof & Powys & $\begin{array}{l}\text { St Fagan's Museum of Welsh } \\
\text { Life }\end{array}$ \\
\hline 1731 & Keal & Lincs & Louth Museum \\
\hline 1742 & Breeds & Sussex & Rye Town Hall \\
\hline Late 18 th century? & Anon & London & $\begin{array}{l}\text { Museum of London } \\
\text { Docklands }\end{array}$ \\
\hline $1777 ?$ & Hill? & Hampshire & Winchester Westgate \\
\hline 1785 & Cliffen & Norfolk & Norwich Castle Museum \\
\hline 1786 & Matcham & Huntingdonshire & St Ives Museum \\
\hline 1787 & Tull or Hawkins & Berkshire & Reading Museum \\
\hline 1791 & Miles & Lancs & Warrington Museum \\
\hline 1794 & Nicholls & Suffolk & $\begin{array}{l}\text { Moyses Hall Museum, Bury } \\
\text { St Edmunds }\end{array}$ \\
\hline 1795 & Watson & Norfolk & Norwich Castle Museum \\
\hline 1795 & Quin or Culley & Cambs & $\begin{array}{l}\text { Wisbech and Fenland } \\
\text { Museum }\end{array}$ \\
\hline 1806 & Otter (Temporell) & Lincs & Doddington Hall \\
\hline 1832 & Jobling & Northumberland & $\begin{array}{l}\text { South Shields Museum (pos- } \\
\text { sible replica) }\end{array}$ \\
\hline 1832 & Cook & Leics & $\begin{array}{l}\text { Nottingham Galleries of } \\
\text { Justice (replica in Leicester } \\
\text { Guildhall) }\end{array}$ \\
\hline
\end{tabular}

impossible to retain the composure he had exhibited during sentencing, according to a contemporary newspaper report. ${ }^{39}$

Even with the ability to start making the gibbet irons while the condemned man was still alive, there could be considerable time pressure. Moreover, careful measuring of the body to be enclosed was not always possible, and sometimes the condemned man resisted this horrible reminder of his imminent fate. Thus, despite attempts to make the gibbet irons adjustable, designs were not always successful: in 1750, the London Evening Post records that the body of John Barchard had to be taken back to the gaol after his execution while the gibbet irons were altered, "they proving too little" (29 September 1750). Some gibbet

\footnotetext{
${ }^{39}$ Lloyds Evening Post, 21-23 March 1792, issue 5419.
} 


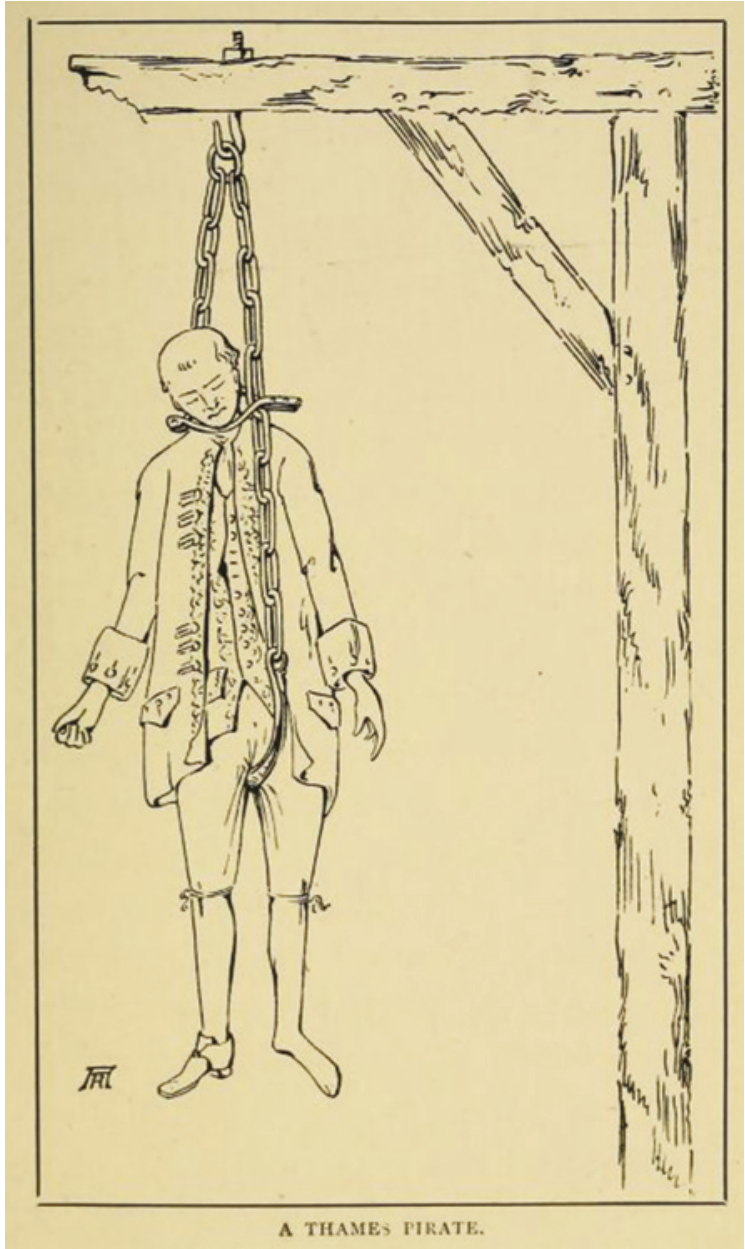

Fig. 2.5 A Thames pirate (from Hartshorne Hanging in Chains)

contraptions were so basic that the size or shape of the corpse made little difference. Hartshorne (1891: 77) shows 'a Thames pirate' suspended in what is apparently a single chain with a gusset passing between the legs and a brace around the neck to keep the body upright (Fig. 2.5). It would be easy to remove a body from such a rig, nor would it keep the 


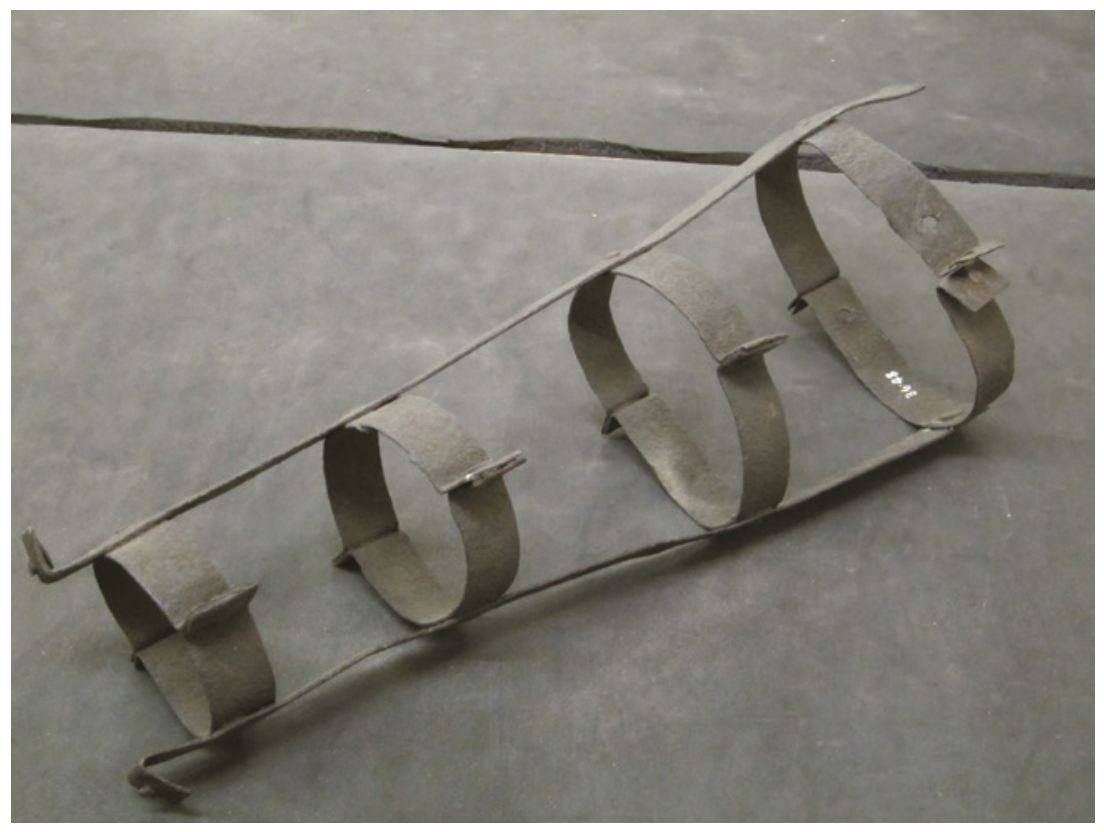

Fig. 2.6 Tull or Hawkins's leg iron, courtesy of Reading Museums (photo: Sarah Tarlow)

body together for long once decay began to accelerate, so such a design could not have been a very successful gibbet for the long term. Surviving gibbet cage structures show that they were often constructed so as to be adjustable to fit the size and shape of the particular body they came to enclose. On the Keal gibbet at Louth, for example, both the belt bands and the long straps are punched several times so that the framework could be extended or contracted and bolted into place to fit supportively close to the body. In the collection of Reading museum, a similar design is evident on the leg iron of Tull or Hawkins's gibbet, which can be tightened to suit the circumference of the leg (Fig. 2.6). Although some gibbet cages, like James Cook's of Leicester, have rigid, hinged hoops, others allow for some degree of shaping to the criminal's body. Only a small part of Gervase Matcham's gibbet survives at Norris House museum, St Ives: part of what is probably a belt, made of a series of five 
curved and hinged plates which probably would have conformed quite closely to the shape and size of the condemned man's waist.

Usually the fitting of the irons is not described in the sources, but occasionally the cravings mention a cost for having the smith attend the execution in order to fit the irons afterwards. The account of John Curtis's hanging in chains in Wiltshire in 1764 mentions that the smith who made the chains was also responsible for fitting them and was paid to travel to the execution for this purpose. ${ }^{40}$ When Rider Haggard discovered the remains of the gibbet and skeleton of Stephen Walton while digging on West Bradenham common, Norfolk, he noticed that the skull had clear scorch marks where it had been burned by a hot iron, thus proving to Rider Haggard that the man must have been dead when enclosed in his gibbet cage and to us that the smith on that occasion fitted the gibbet by soldering or welding. ${ }^{41}$ The fact that newspapers commented on the return of John Barchard's body to the gaol after his execution so that the irons could be re-sized suggests that normally the irons were fitted directly after and at the scene of execution. ${ }^{42}$ This also constitutes circumstantial evidence that tarring the body was not normally practised, or was a very quick and easy process, since it is hard to see how a corpse could be stripped, immersed in tar, redressed and fitted into irons in a very short time and at the foot of the scaffold.

The poles from which the cages were hung were often very high-10 metres or more, which discouraged attempts to rescue the body or to steal the gibbet - and supported chains which comprised a substantial quantity of iron. The post was also sometimes fitted with spikes around the bottom to make it hard to scale. The gibbet post of Adam Graham, executed in 1748 and hung in chains on Kingmoor, Carlisle, was apparently 12 yards

\footnotetext{
${ }^{40}$ TNA T90/155, Sheriff's Cravings.

${ }^{41}$ H. Rider Haggard (1899) A Farmer's Year (London: Longman's, Green and Co), p. 355. Sadly, no scorch marks are evident on the skull fragments which are held today by Norwich Castle Museum, but this may be due to over-zealous cleaning shortly after acquisition.

${ }^{42}$ However, the Old England Journal for 28 January 1749 records that the bodies of smugglers Comby, Hammond, Carter and Tapner were returned to the gaol after their execution in order to be hung in chains, which could indicate that the fitting of the gibbet cages was done at the gaol. The body of a fifth man, their partner Jackson, was already at the gaol, where he had died two hours after being sentenced to hang in chains, being "so terribly frightened". It is not possible to say from the newspaper report whether the untimely end of Jackson altered the normal course or location of fitting the irons.
} 
high and had 12,000 nails in it to prevent it being scaled or cut down to remove the body. ${ }^{43}$ The sheriffs' cravings for Hampshire in 1761 note that when Francis Arsine was hung in chains the gibbet was "20 feet high made of very strong timber and secured with nails to prevent its being cut down and [fitted with] a secure set of chains". Several London gibbeting accounts (in the sheriffs' cravings) make reference to "plating the gibbet". The fairly detailed accounts for the gibbeting of Thomas Willot in Staffordshire in 1739 include "timber for the gibbet 28 foot long (being 7 yards or thereabout above ground) and cross pieces and carriage there of workmanship of the timber and erecting the gibbet and lining gibbet on each side with bars of iron". Similarly, the cravings account for the gibbet of William Corbett (executed in Surrey in 1764) itemises "the gibbet made strong with iron to prevent it being cut".

The gibbet pole seems almost always to have been made from timber, although sometimes the cravings specify that the timber is "strong" or note that nails or iron bars or plates, as discussed above, should reinforce the main post. The sheriff who commissioned the three-armed gibbet erected for the bodies of Drury, Barker and Lesley in Warwickshire in 1765 lists "materials of stone and timber" for the gibbet, but stone is not usually mentioned in connection with a gibbet, and there is no indication of what its role was to be-perhaps to construct a strong socket for the post. A broken socket stone at Gonerby Hill Foot, Lincolnshire, is believed locally to have supported a gibbet at one time. ${ }^{44}$

\section{Extant Gibbets}

I have been able to discover the whereabouts of only 16 extant gibbet cages, despite a thorough literature and online search and an appeal on national radio. The majority of gibbets seem to have disappeared. Those gibbets that do exist are in a variety of styles. The surviving evidence is considered briefly here ${ }^{45}$ :

\footnotetext{
${ }^{43}$ Hartshorne Hanging in Chains, pp. 66-67.

${ }^{44}$ http://www.lincstothepast.com/photograph/290331.record?pt=S.

${ }^{45}$ See Sarah Tarlow (2014) 'The technology of the gibbet' International Journal of Historical Archaeology 18: 668-99 for a fuller discussion. The chains at Weston Park museum, Sheffield, catalogued as Spence Broughton's gibbeting chains are in fact restraining chains and manacles, and another set of chains, perhaps horse furniture. They do not resemble any other gibbet irons and are not included in Table 2.3.
} 
These gibbets show a variety of forms. Some have hooped extensions for arms and legs, others for legs only, and John Keals's gibbet at Louth has only a headpiece and torso, from which the arms and legs would have dangled. Figure 2.7 shows some different styles of gibbet.

\section{The Necessary Functions of a Gibbet}

What functions must an effective set of irons fulfil? First, it must contain the body and prevent it from either falling out or being removed, while at the same time still maximising its visibility. In order to do this, most gibbet cages were designed to fit closely to the body, allowing as much as possible of the body to be seen, while ensuring that the gaps between bars were too small to remove it. When possible, the prisoner was measured for his irons before execution, but there were other means of ensuring a close fit, notably construction with punched straps and hoops that could be adjusted to size by riveting (Fig. 2.8). Bodies in advanced decay would necessarily have fallen through the framework in pieces, although the skull, if unbroken, might remain in the headpiece, as in the case of John Breeds at Rye or Sion y Gôf at Dylife (Fig. 2.9). In addition, small pieces of the body could easily be removed by animals or birds. However, by adding to the horror of the gibbeted body, such removals did not diminish the power of the spectacle. In fact, the power of carrion birds around the gibbet to augment the horror was exploited in artistic depictions of the gibbet (Fig. 2.10).

Strength and security seem to have been the most valued and discussed features of a good gibbet. The cravings often describe the gibbet as "strong" and sometimes specify the necessity of making theft of the body impossible. The sheriffs' cravings for Berkshire 1738, for example, mention that the irons of John Sturabout cost $£ 7$ and 7 shillings "to prevent [his body] being stolen wherein much iron and workmanship is required". The cravings related to the gibbetings of David Anderson (1736) and William Fairall (1749) in Kent both make explicit reference to the need for security. Anderson's gibbet was "built in a strong manner and filed with nails and braced with iron to prevent the same from being cut down", and Fairall's gibbet was also riveted with iron to prevent his fellow smugglers from cutting 

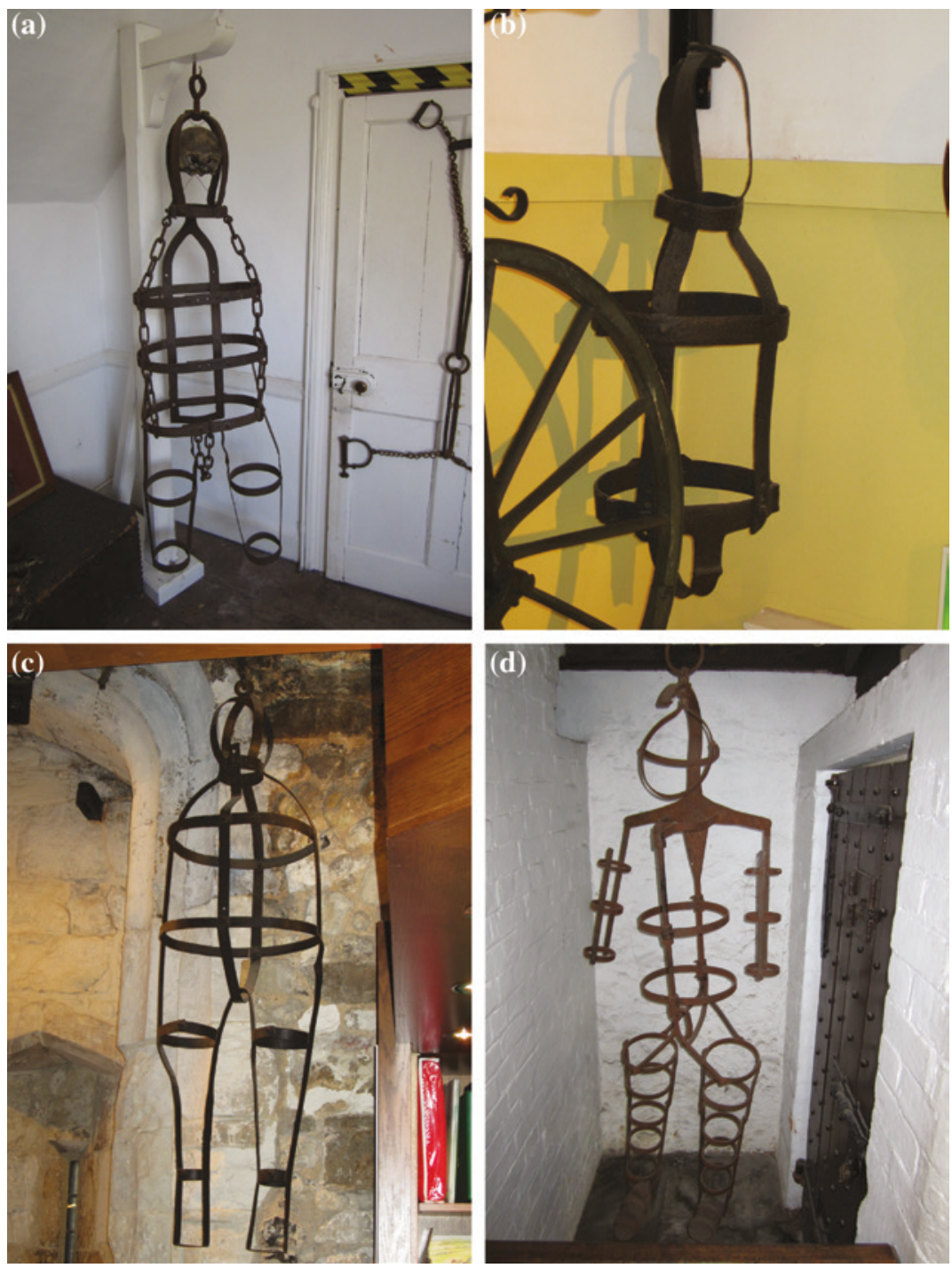

Fig. 2.7 Some different styles of gibbet: a: John Breeds (Rye, 1743, now in Rye town hall); b: John Keal (Louth, 1731, now in Louth Museum); c: possibly 'Jack the Painter' (Portsmouth, 1777, now in Winchester Museum); James Cook (Leicester, 1832, replica now in Leicester Guildhall). All photos: Sarah Tarlow 
Fig. 2.8 Multiple punches holes on John Keal's gibbet (photo: Sarah Tarlow)

Fig. 2.9 Headpiece of John Breeds's gibbet with large skull fragment remaining (photo: Sarah Tarlow)
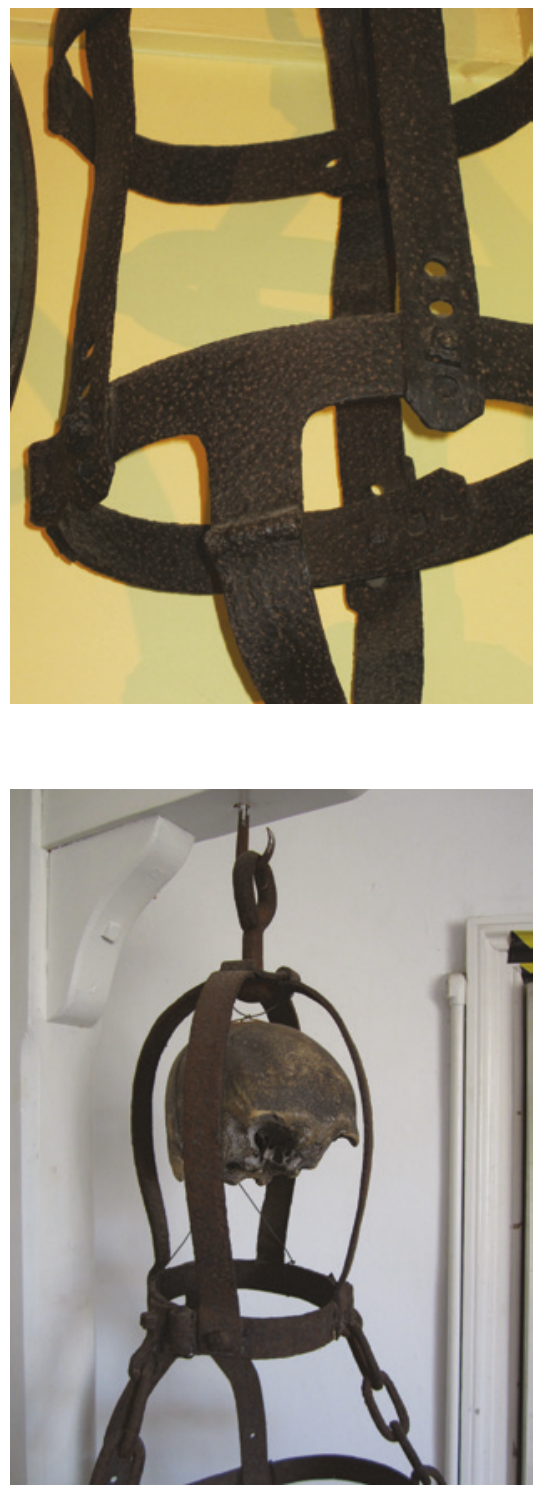


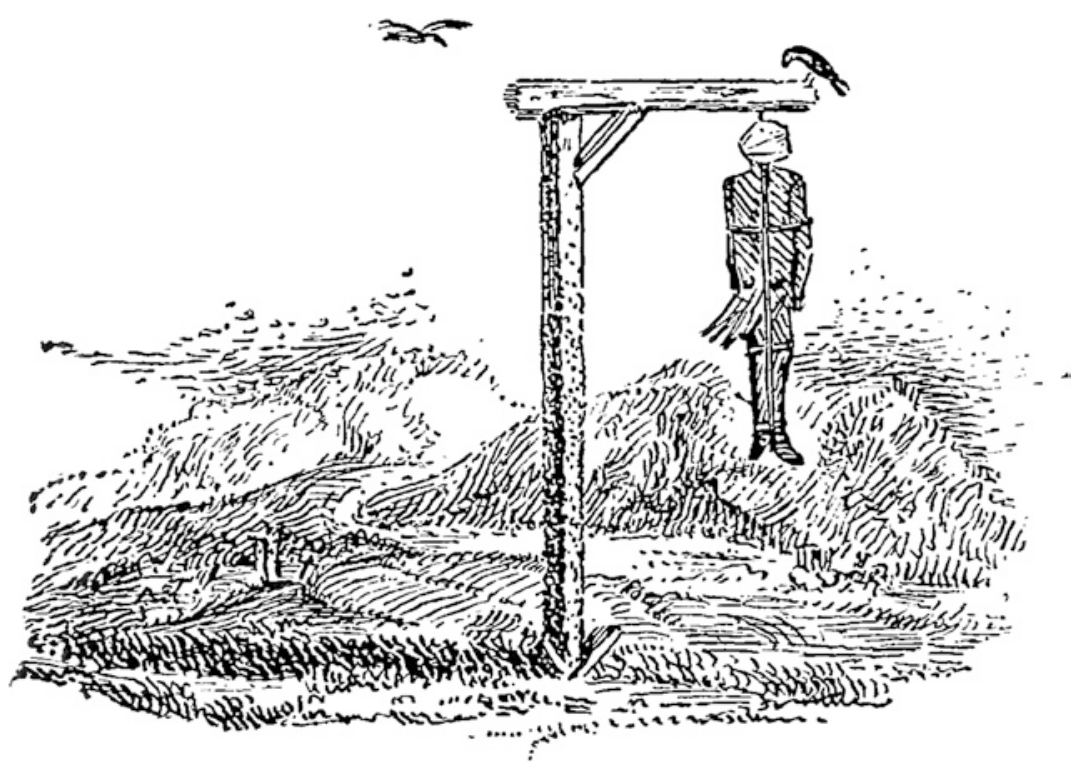

Fig. 2.10 Artistic representation of a gibbet with carrion birds. Vignette from Thomas Bewick's British Birds (1804)

him down. ${ }^{46}$ The journalist for the Daily Courant ${ }^{47}$ who reported on John Naden's hanging in chains in Staffordshire was impressed by the chains, made by somebody from Birmingham "in so curious a Manner, that they will keep his Bones together till they turn to Powder, if the Iron will last so long".

Second, the gibbet cage must be conspicuous. This was achieved largely through the use of a tall pole and advantageous siting (sometimes taking advantage of a natural or archaeological eminence such as a hillock or barrow) adjacent to well-used public roads. The successful cage should make the body more visible and more terrible to onlookers. The gibbet cage must contribute to the awe of the spectacle by allowing the body to be seen and permitting some limited movement. If this also caused the

\footnotetext{
${ }^{46}$ TNA T90/147/256 Sturabout; T90/147/118 Anderson; T64/262 Fairall.

${ }^{47}$ Daily Courant, 13 September 1731.
} 
chains to creak or clang, so much the better. The Reverend Charles Hardy remembered an occasion in about 1837, driving over West Bradenham Common at night when his horse began to "plunge violently" and he heard a sound above his head: "Clink, clank; clink, clank; clink, clank". His servant told him it was the sound of a gibbet "on which the iron cap and collar of the man, who had been hanged, was swinging to and fro in the October breeze, producing the ghastly sound". 48

Third, the gibbet cage had to be durable. The body was supposed to remain up there until it had decayed, and as there was no particular time for taking it down, many gibbets remained in their location for decades. Heavy iron was invariably used for the cage. The condition of surviving gibbets is testament to their durability, especially since many of them had been hanging outside for many decades, often followed by a period of burial in wet ground.

Fourth, it had to be possible to construct a gibbet cage quickly. As we have seen, less than a week was available to design and construct the full kit in most cases. The smith had to work together with a carpenter (whose job it was to make the wooden pole), to ensure that the gibbet was securely erected in time for the arrival of the body, and then to encase the body in its irons and probably to oversee its suspension.

Fifth, while being durable and secure, the gibbet cage also had to be light enough to hoist on a gibbet post which could be around ten metres high and not so solid that the visibility of the body was in any way impeded. The criminal on the gibbet should be recognisable to those who had known him in life.

\section{Gibbet Technology and the Absence of Tradition}

Gibbeting required a pole/scaffold, a length of chain, and a gibbet cage or suit. The sheriffs' cravings normally bundle all these costs together, but sometimes they specify the recipient of the money and the nature of their job. For example, John Bowland's gibbet, commissioned in

\footnotetext{
${ }^{48}$ Hardy's work, Social England from eighty years ago to the present jubilee year, is cited by C.M. in the Norfolk Chronicle of 1897 (30 January 1897). This must have been Watson's gibbet of 1795, despite C.M.'s stated belief that a gibbet of such a date would not be standing in the later 1830s. In fact, many gibbets are known to have been still standing fifty years or more after their erection.
} 
Rutland in 1769 , cost $£ 5,15$ s, 6d for the "set of iron chains", paid to John Fox, a blacksmith, and $£ 6,2 \mathrm{~s}, 6 \mathrm{~d}$ for the construction and erection of the wooden gibbet frame, paid to John Wyhters, a carpenter.

The gibbet cage is an unusual artefact. It is comparatively rare-out of only a couple of hundred (at most) that formerly existed in Britain, only a handful are known. The infrequency of its manufacture makes it unusual also. Blacksmiths in Britain during the eighteenth and nineteenth centuries generally made few forms-agricultural implements, craft tools, household objects and farriery (horse-shoeing and horse tack). These artefacts were learned during long apprenticeships and conform to local traditions. ${ }^{49}$ By contrast, a gibbet was needed so infrequently that it was not a form within the learned repertoire of most blacksmiths. Moreover, it was needed almost immediately and so left the blacksmith little time to experiment or research other models. Therefore, each blacksmith needed to design a gibbet effectively from scratch. This constant reinvention of the gibbet iron is evident in the proliferation of designs and in the absence of clear typological logic by either region or time period, even though such typologies are observable in other, more frequently made, products of the blacksmith's craft. The range of designs identified represent independent and idiosyncratic responses to the problem of designing a framework which would enable the range of functions identified above.

\section{The 'Carnival' of the GibBet}

Huge crowds are commonly reported in the days immediately following the erection of a gibbet. At least 2000 people are supposed to have visited the scene of Benstead's gibbet on Undley Common, Suffolk on a single day in 1792, and maybe 200 of them made a special ferry crossing in order to visit the site. ${ }^{50} \mathrm{~A}$ similar number was estimated to have attended the gibbeting of Robert and William Drewitt on North Heath Common in 1799; on that occasion, the spectators were accommodated in booths "as

${ }^{49}$ J. Bailey (1977) The Village Blacksmith (Princes Risborough: Shire); E. J. T. Collins (1996) 'Agricultural hand-tools and the industrial revolution', in N. Harte and R. Quinault (eds.), Land and Society in Britain, 1700-1914 (Manchester: Manchester University Press) pp. 57-77.

${ }^{50}$ World, April 1792, issue 1651. 
at a horse race or cricket match". ${ }^{11}$ Such numbers, however, were dwarfed by the estimated 40,000 who attended the first day of Spence Broughton's gibbeting near Sheffield or William Smith's on Finchley Common.

What did the gibbet crowd experience? Between the expectation that they would have been unanimously awed and chastened by the spectacle of ignominy and the revisionist position that they subverted the theatre of humiliation, there is a wide spectrum of possible reactions. Gatrell's critique of Laqueur's posited "carnival" of the scaffold questions the idea that the crowd rather than the State was in control of the scaffold experience. ${ }^{52}$ While potentially subversive and "carnivalesque" elements were undoubtedly present at the scene of an execution, the disapproval with which such scenes were described in the contemporary press suggests that it should not be seen as normative behaviour. Gatrell's comments on Laqueur refer only to the scene of execution. How far their debate could be relevant to subsequent hanging in chains will be discussed further in the conclusion. There was no doubt a big difference between visiting a gibbet at or shortly after its erection and encountering a gibbet months or years later. There is no doubt that for many people the gibbet represented simply another destination for a day out. Stephen Monteage of London recorded in his diary for the 16 September 1733: "In the afternoon took a walk with my wife, Mrs Tickling and pretty little Salley to the men in chains upon Stanford Hill". ${ }^{53}$

If the criminal was sufficiently notorious and interest in his gibbet was great, there was good money to be made from playing to these crowds. The landlord of The Arrow on Clifton Lane next to Attercliffe Common, South Yorkshire, where Spence Broughton was gibbeted, boasted that he had made enough money from the beer sold in the first few days of his exhibition that he was able to retire. A description of the gibbet of William Smith on Finchley Common in 1782 remarks that the 40,000 people who came to view the body the Sunday after his

${ }^{51}$ Evening Mail, 17-19 April 1799.

${ }^{52}$ Gatrell The Hanging Tree, pp. 90-105, commenting on T.W. Laqueur (1989) 'Crowds, carnivals and the English State in English executions, 1604-1868', in A.L. Beier et al. (eds.) The First Modern Society: essays in honour of Lawrence Stone. Cambridge: Cambridge University Press, pp. 305-99.

${ }^{53}$ LMA CLC/479/MS00205/001-009. 
execution were well fed. Sausages, fried under the gibbet, were available to the more refined class of people who arrived in coaches, chariots and phaetons while the lower ranks, presumably arriving on foot, were sold gin and gingerbread. ${ }^{54} \mathrm{~A}$ similar number apparently attended the Derbyshire gibbet of Anthony Lingard on its first day, and the local vicar, finding nearly all of his parishioners absent from church, decided instead to give his sermon at the site of the gibbet. ${ }^{55}$

A recently erected gibbet seems often to have attracted a carnival crowd which did not always earn the moral approval of the press. The scene at the gibbets of Peter Conoway and Michael Richardson on Bow Common, London in 1770 were widely reported. Several journals disapproved of the erection of drinking booths and the disorderly behaviour of the "mob" at the site. The General Evening Post described how "Several people have climbed up the gibbet, and some of them have taken the caps from the malefactors' faces. One fellow had the hardness to call out 'Conoway, you and I have often smoked a pipe together, and so shall we again' on which, to no small diversion to the mob, he climbed up the gibbet with two lighted pipes, one of which he stuck in Conoway's mouth, and the other he smoked as he sat across the gallows". ${ }^{56}$ The Public Advertiser, meanwhile, opined that the behaviour of the crowd "must give foreigners a shocking idea of the manners of the English" and was appalled that "what is intended as a public example should be treated as a matter of public festivity". ${ }^{57}$

The size of the crowds at the scene of the gibbet fuelled middle-class anxieties about crime and unrest. Robert Hazlitt, hung in chains near Newcastle in 1770 for robbing the mail, expressed shortly before death the desire that his death and display would be "useful to mankind", presumably as a warning against criminal behaviour. ${ }^{58}$ However, the proximity of the gibbet seems not to have had a reliably deterrent effect on the criminally minded. In 1826, John Lingard was convicted of assault and robbery committed within sight of the gibbet containing the bones of

\footnotetext{
${ }^{54}$ Public Advertiser, 30 April 1782, issue 14927.

${ }^{55}$ C. Drewry (2007) Wormhill: history of a High Peak village (Little Longstone: Ashridge Press).

562-4 August 1770, issue 5744.

${ }^{57}$ Public Advertiser, 6 August, issue 11111; 24 July, issue 11106.

${ }^{58}$ John Sykes, Local Records, vol. 1.
} 
his brother Anthony, executed eleven years earlier. ${ }^{59}$ Nor was this the first serious crime to have been committed at that scene: in 1819, 16-year-old Hannah Bocking chose the road near Lingard's gibbet as the location to give poisoned cakes to Jane Grant, a young woman of her own age who had been offered a job for which Bocking had been turned down. ${ }^{60}$ For this crime, Bocking herself was executed and dissected. The same year the Sheffield Iris reported a robbery near Attercliffe, pointing out that the "daring offender must have passed through the field in which is the gibbet of the notorious Spence Broughton". ${ }^{61}$

\section{The Curative Power of the Gibbeted Man}

Gibbeted bodies not only were magnets for fairs and wild behaviour but also were the unlikely subjects of eighteenth-century medical tourism, sought for their curative and totemic value as sources of healing. The touch of the dead man's hand was believed to cure various diseases and, in former times, had even been recommended by orthodox medical authorities such as William Harvey. ${ }^{62}$ There are several accounts of people visiting gibbets specifically to stroke the affected parts of their bodies with the dead man's hand. In 1799, two young women "of genteel appearance" came to the gibbets of Robert and William Drewitt on North Heath in order to have their necks stroked by the hand of one of the dead men in order to cure their scrofula. ${ }^{63}$ In the ensuing months, many people travelled to the site of the gibbet with their children in order to hold them up towards the body of Robert Drewitt, who was widely believed to have been wrongly executed, to have his hand passed over their throats. A newspaper search revealed 27 instances of curative uses of the hanged man's hand between 1758 and $1863 .{ }^{64}$ It is mostly the newly hanged

\footnotetext{
${ }^{59}$ The Derby Mercury, 22 March 1826, issue 4889.

${ }^{60}$ Taylor. May the Lord have mercy on your soul, p. 40.

${ }^{61}$ Sheffield Iris, 6 April 1818. Thanks to Chris Williams for drawing this report to the attention of the research project.

${ }^{62}$ W. Pagel (1976) New light on William Harvey (Basel: S. Karger) p. 50.

${ }^{63}$ Courier and Evening Gazette, 24 April 1799, issue 2088.

${ }^{64} \mathrm{O}$. Davies and F. Matteoni (2015) 'A virtue beyond all medicine': The Hanged Man's Hand, Gallows Tradition and Healing in Eighteenth- and Nineteenth-century England. Social History of Medicine.
} 
man's hand that was sought after, while still hanging from the scaffold on which the execution had taken place. Touching the hand of a gibbeted criminal must have been challenging, given the height of the post and the rigid design of many cages. The curative use of the bodies of the Drewitt brothers was, in that sense, unusual, and it is possible that the particular draw of those bodies related to the availability of a ladder or a particularly accessible set of irons or both, although such a suggestion is purely speculative. In other ways, however, the gibbet, and the bones contained within it, continued to have power over the bodies, minds and landscapes of the living for many decades, as we shall see in Chap. 3.

Open Access This chapter is licensed under the terms of the Creative Commons Attribution 4.0 International License (http://creativecommons.org/licenses/ by $/ 4.0 /)$, which permits use, sharing, adaptation, distribution and reproduction in any medium or format, as long as you give appropriate credit to the original author(s) and the source, provide a link to the Creative Commons license and indicate if changes were made.

The images or other third party material in this chapter are included in the chapter's Creative Commons license, unless indicated otherwise in a credit line to the material. If material is not included in the chapter's Creative Commons license and your intended use is not permitted by statutory regulation or exceeds the permitted use, you will need to obtain permission directly from the copyright holder.

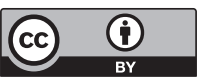

